\title{
Influence of salinity and linoleic or -linolenic acid based diets on ontogenetic development and metabolism of unsaturated fatty acids in pike perch larvae (Sander lucioperca)
}

Lund, Ivar; Rodríguez, Covadonga; Izquierdo, Maria S.; El Kertaoui, Najale; Kestemont, Patrick; Reis, Diana B.; Dominguez, David; Pérez, Jose A.

\section{Published in:}

Aquaculture

Link to article, DOI:

10.1016/j.aquaculture.2018.10.061

Publication date:

2019

Document Version

Peer reviewed version

Link back to DTU Orbit

Citation (APA):

Lund, I., Rodríguez, C., Izquierdo, M. S., El Kertaoui, N., Kestemont, P., Reis, D. B., Dominguez, D., \& Pérez, J. A. (2019). Influence of salinity and linoleic or -linolenic acid based diets on ontogenetic development and metabolism of unsaturated fatty acids in pike perch larvae (Sander lucioperca). Aquaculture, 500, 550-561. https://doi.org/10.1016/j.aquaculture.2018.10.061

\section{General rights}

Copyright and moral rights for the publications made accessible in the public portal are retained by the authors and/or other copyright owners and it is a condition of accessing publications that users recognise and abide by the legal requirements associated with these rights.

- Users may download and print one copy of any publication from the public portal for the purpose of private study or research.

- You may not further distribute the material or use it for any profit-making activity or commercial gain

- You may freely distribute the URL identifying the publication in the public portal 


\section{Accepted Manuscript}

Influence of salinity and linoleic or $\alpha$-linolenic acid based diets on ontogenetic development and metabolism of unsaturated fatty acids in pike perch larvae (Sander lucioperca)

Ivar Lund, Covadonga Rodríguez, Maria S. Izquierdo, Najale El Kertaoui, Patrick Kestemont, Diana B. Reis, David Dominguez, Jose A. Pérez

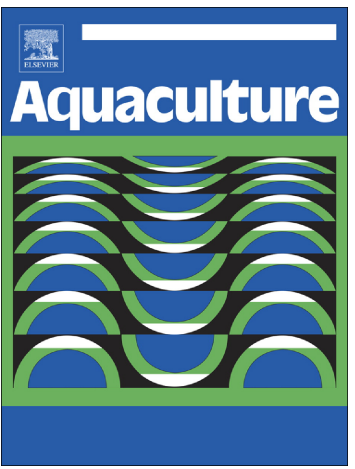

PII: S0044-8486(18)30008-5

DOI: doi:10.1016/j.aquaculture.2018.10.061

Reference: AQUA 633652

To appear in: aquaculture

Received date: 2 January 2018

Revised date: 13 September 2018

Accepted date: 25 October 2018

Please cite this article as: Ivar Lund, Covadonga Rodríguez, Maria S. Izquierdo, Najale El Kertaoui, Patrick Kestemont, Diana B. Reis, David Dominguez, Jose A. Pérez, Influence of salinity and linoleic or $\alpha$-linolenic acid based diets on ontogenetic development and metabolism of unsaturated fatty acids in pike perch larvae (Sander lucioperca). Aqua (2018), doi:10.1016/j.aquaculture.2018.10.061

This is a PDF file of an unedited manuscript that has been accepted for publication. As a service to our customers we are providing this early version of the manuscript. The manuscript will undergo copyediting, typesetting, and review of the resulting proof before it is published in its final form. Please note that during the production process errors may be discovered which could affect the content, and all legal disclaimers that apply to the journal pertain. 
Influence of salinity and linoleic or $\alpha$-linolenic acid based diets on ontogenetic development and metabolism of unsaturated fatty acids in pike perch larvae (Sander lucioperca)

Ivar Lund ${ }^{\mathrm{a}}$, Covadonga Rodríguez, Maria S. Izquierdo ${ }^{\mathrm{c}}$, Najale El Kertaoui ${ }^{\mathrm{d}}$, Patrick Kestemont ${ }^{\mathrm{d}}$, Diana B. Reis ${ }^{\mathrm{b}}$, David Dominguez ${ }^{\mathrm{c}}$, Jose A. Pérez ${ }^{\mathrm{b}}$

${ }^{a}$ Technical University of Denmark, DTU Aqua, Section for Aquaculture, The North Sea Research Centre, P.O. Box 101, DK-9850 Hirtshals, Denmark. il@aqua.dtu.dk

bDepartamento de Biología Animal, Edafología y Geología, Universidad de La Laguna, Avenida Astrofísico Francisco Sánchez s/n, 38206 La Laguna, Spain

${ }^{c}$ Aquaculture Research Group (GIA), ECOAQUA Institute, Universidad de Las Palmas de Gran Canaria, Crta. Taliarte s/n, 35214 Telde, Spain.

${ }^{\mathrm{d}}$ Research Unit in Environmental and Evolutionary Biology, University of Namur, Rue de Bruxelles, 61 - 5000 Namur, Belgium

Corresponding author Ivar Lund: il@aqua.dtu.dk, Ph: +4524893963

\begin{abstract}
Combinations of nutritional requirements and husbandry rearing conditions during early ontogeny are poorly studied in pikeperch (Sander lucioperca). The substitution of marine oils with vegetable oils has reduced stress tolerance and caused neurophysiological changes in pike perch larvae, but effects of environmental cues are limited. Saline water influences on a range of physiological functions during early fish larval ontogeny and may affect FA metabolism, - elongation and desaturation - activity when given diets limited in LC PUFAs, but rich in shorter chain n-3 or n-6 PUFAs. Consequently, live Artemia differing in 18:2n-6 (LA) and 18:3n-3 (ALA) content by enrichment with sunflower oil (SFO) or linseed oil (LO) were fed to 10 days post hatch (DPH) larvae and reared up to isosmotic salinities (0, 5, 10 ppt) until 30 DPH. Larval tissue FA composition was examined at 15, 25 and $30 \mathrm{DPH}$. Besides, an in vivo assay was performed on 20 DPH larvae with ${ }^{14} \mathrm{C}$ labelled FA including LA; ALA; 20:4n-6 (ARA); 20:5n-3 (EPA) or 22:6n-3 (DHA) to establish FA incorporation and metabolism. At $30 \mathrm{DPH}$, performance, digestive enzymatic activity, eicosanoid activity, skeletal anomalies and stress sensitivity were further evaluated. Results on larval FA profiles suggest a low desaturation and elongation capability over
\end{abstract}


LA and ALA, with no significant effects of salinity or larval age on modulation of unsaturated fatty acid metabolism. In vivo assays revealed that regardless of salinity or diet, pikeperch possess a marked specificity to incorporate ARA and EPA compared to a poorer incorporation of DHA. Larvae exposed to a confinement stress test caused high acute mortality in all experimental groups except for a control group fed with Artemia enriched by a commercial DHA Selco emulsion. Growth performance was not significantly affected by salinity or dietary enrichment with SFO or LO, but influenced on larval enzymatic activity of pepsin, aminopeptidase, trypsin and alkaline phosphatase, while lipase activity was not significantly affected. Increased saline conditions significantly decreased hormonal prostaglandin eicosanoid $\mathrm{PGE}_{2}, \mathrm{PGE}_{3}$ activity with the highest activity at 0 ppt. The prevalence of severe skeletal anomalies was generally high, affecting over $75 \%$ of the larval population with negative effects by increase in salinity. The incidence of anomalies was higher on endochondral bones, namely maxillary, ranging from $58-83 \%$ of the population. These results agree well with those from expression of sox 9 and twist 2 genes; involved in chondrocyte ossification and differentiation.

Keywords: Sander lucioperca, salinity, HUFA, eicosanoids, enzymes, gene expression, metabolism.

\section{Introduction}

Pikeperch is a piscivorous percid fish originating from the Caspian-Black Sea region, but has spread throughout most of mainland Europe (Craig, 2000). Though regarded as a stenohaline fish, pikeperch populations in brackish water for instance in the Baltic Sea have an anadromous lifehistory strategy similar to those of salmonids; as they use the coastal environment in the Baltic Sea as forage habitat but migrate to streams and brooks for reproduction. Pikeperch aquaculture has gained commercial interest in recent years and farming methods in Europe are in transition from traditional more extensive freshwater pond farming to intensive closed recirculation aquaculture systems (RAS) (Dalsgaard et al., 2013; Kestemont et al., 2015). Despite farming of this species takes place in freshwater, studies have shown a relatively high level of osmotic tolerance and degree of hypo-osmoregulatory capacity in a saline environment. This is not common for most other stenohaline freshwater teleosts (Brown et al., 2001), but may suggest a growth potential for rearing in low saline waters. Larvae are relatively undeveloped at hatching and do not have the same 
osmoregulatory capacity (i.e. integument, gills, urinary bladder, complete functional gut, kidneys) as metamorphosed larvae or later stage juveniles, but most teleost's larvae are able to osmoregulate due to a high density of ionocytes in the prelarval integument that acts as temporarily osmoregulatory site. Limited knowledge exist about influence of hyperosmotic or isosmotic salinity on early pike perch larval ontogeny or physiology. Environmental changes in salinity have shown to result in modification of physico - chemical conditions of the gut lumen in other fish larvae and may exert a direct action on digestive enzyme performance (Boef and Payan, 2001) as well as food transition time (Gheisvandi et al, 2015), that may have implications on growth performance.

Additionally, salinity has shown variable effects on the modulation and expression of $\Delta 6$ desaturase activity and fatty acid composition in fishes as previously reviewed (Vagner and Santigosa, 2011) affecting quantitative PUFA requirements of a same fish species reared at different salinities (Izquierdo and Koven, 2010). In Atlantic salmon (Salmo salar), the LC-PUFA synthesis pathway is affected by environmental cues during transfer to seawater that modulate the expression of fatty acyl desaturase genes in freshwater and seawater phases (Zheng et al., 2005). The rabbitfish Siganus canaliculatus, an euryhaline herbivorous, has a higher ability to convert LA and LNA to LC-PUFAs when reared in lower salinities (Li et al., 2008; Xie et al., 2015). In the freshwater Mexican silverside (Chirostoma estor) LC-PUFA biosynthesis from C18 precursors was detected at low salinities (5, $15 \mathrm{ppt}$ ), whereas this pathway is not active in fish reared in freshwater (FonsecaMadrigal et al., 2012). Studies on the effect of salinity on fatty acids requirements and biosynthesis pathways are scarce (Izquierdo and Koven, 2010). For instance, larvae of the euryhaline common galaxias (Galaxias maculatus) reared at different salinities (0-15 ppt) denoted a higher DHA requirement at higher salinities (Dantagnan et al., 2010) and a higher PUFA (18:3n-3) requirement at 0 ppt (Dantagnan et al, 2013).

The limitations in production of marine oils as due to the increasing demand has caused interest in research into effects of partial or total substitution by oils of plant origin. The early dietary deprivation of EPA, DHA and ARA by use of vegetable oils may give valuable information on dietary programming and implications for physiological pathways in fish larvae as observed in rainbow trout fry (Geurden et al., 2013; Balasubramanian et al, 2016). Diets low in LC-PUFAs, especially DHA, may not affect growth of pike perch, but has provoked increased mortality; shock syndromes; short and long-term stress sensitivity; and deficiency in neural development during early ontogeny, that may affect behavior and learning (Lund and Steenfeldt, 2011; Lund et al., 2014). This suggests a low elongation/desaturation capacity in pikeperch in freshwater in contrast to 
many other omnivorous or carnivorous freshwater fish species, that have a relatively low LC-PUFA requirement and a certain capability to elongate and desaturate C18 carbon PUFAs such as linoleic acid (18:2n-6, LA) and $\alpha$-linolenic acid (18:3n-3, ALA) to LC-PUFAs of C20 or C22 carbons, i.e. ARA, EPA and DHA (Tocher, 2010; Xie et al., 2015). In Eurasian perch (Perca fluviatilis), dietary partial substitution of fish oil with vegetable oils and an increased dietary proportion of LA/ALA did not affect growth performance, but increased fatty acid elongation and desaturation activity in liver (Blanchard et al., 2008). Besides, Eurasian perch fed a semi-purified fat free diet over 4 weeks followed by different lipid sources (olive oil, safflower oil, linseed oil, or cod liver oil) as the only lipid source showed significant changes in n-3/n-6 ratio and FA composition; indicating that the competition and inhibition between ALA and LA for further desaturation and elongation were greatly influenced by the type of vegetable fat and the content of n-3 and n- 6 FA in the diet (Xu and Kestemont, 2002). A dietary incorporation of ALA concomitantly to LA seemed to be beneficial in order to stimulate liver $\Delta 6$ and $\Delta 5$ desaturation activity, rate-limiting enzymes involved in LCPUFA biosynthesis (Xu and Kestemont, 2002; Blanchard et al., 2008). In this sense, and in order to improve the understanding of nutritional physiology of marine fish larvae, studies on metabolic fates of fatty acids through radio tracing methodologies are also currently available (reviewed by Conceição et al., 2007). Among them, in vivo incubation of marine larvae with 14C-labeled fatty acid substrates directly added to the rearing water has been successfully used in order to investigate competition and inhibition fates as well as their capability to metabolize dietary FAs (Reis et al., 2014, 2017).

Salinity and dietary ALA/LA ratio may thus influence C20 EPA, DHA and ARA synthesis with possible implications for effects on prostaglandin eicosanoid activity, a group of active hormonelike agents formed from C20 EFA. Their transitory nature fits them to an important role in modulating rapid physiological responses to stimuli while imbalances may impair skeletogenesis during early stages of larval development (Boglino et al., 2014). Successful production of pikeperch juveniles is constrained by the high incidence of skeletal anomalies (Kestemont et al., 2015) and salinity markedly affected the occurrence of skeletal abnormalities in other fishes (Lall and LewisMcCrea, 2007). Fish possess a wide diversity of cartilages and bones, that are formed during embryonic and larval development (Lall and Lewis-McCrea, 2007), including endochondral and intra-membranous bones (Witten and Huysseune, 2009). A series of molecular markers of bone development have been associated with skeletal anomalies (Saleh et al., 2013a,b). For endochondral bones, sox 9 is a key cartilage transcription factor important for craniofacial bone development, 
being expressed in zebrafish in the splanchnocranium and pectoral girdle cartilage (Yan et al., 2002). Subsequently, endochondral ossification is regulated by runx2, also required for osteoblast differentiation, which is inhibited by Twist proteins (Chen et al, 2014). Alkaline phosphatase gene (alp) is a marker of osteoblast differentiation essential for bone matrix mineralization in formation of intra-membranous bones (Hessle et al., 2002). Alp is up regulated by dietary fatty acids in larval gilthead sea bream larvae (Saleh et al., 2013a,b). Twist2 plays an important role in bone development by binding to Runx2, and reducing the formation of osteoblasts from its precursors (Kronenberg, 2004). Finally, mef2c (myocyte enhancer factor 2), a transcription factor that regulates muscle and cardiovascular development, also controls bone development activating chondrocyte differentiation (Arnold et al, 2007). In addition, up-regulation of mef $2 c$ causes precocious chondrocyte hypertrophy and dwarfism (Arnold et al., 2007).

The present study thus examined possible effects of dietary n-3/n- 6 and salinity by enrichment of Artemia with either linseed oil (LO) (high content of ALA) or sunflower oil (SFO) (high content of LA), at low saline rearing conditions (0 ppt; $5 \mathrm{ppt} ; 10 \mathrm{ppt})$ in addition to a control group enriched with a commercial DHA Selco emulsion at 0 ppt salinity. Results were assessed by analyses of larval FA composition during development and their in vivo capability to incorporate selected EFA (LA, ALA, ARA, EPA and DHA) into total lipids, as well as enzymatic and eicosanoid activities, incidence of skeletal deformities, and stress and performance parameters in pike perch larvae until 30 days post hatching (DPH).

) .

\section{Materials and Methods}

\subsection{Experimental set up and feeding}

Fertilized eggs of pikeperch close to hatching were obtained from Aquapri Innovation, Egtved, Denmark and transferred to DTU Aqua at the North Sea Research Centre, Denmark. Eggs were incubated at $17.5^{\circ} \mathrm{C}$ in McDonald jar incubators at a flow rate high enough to keep eggs in suspension. Eggs hatched during the following two days and larvae were roughly counted and distributed to 18 conical transparent $46 \mathrm{~L}$ tanks in a temperature controlled flow through system at $16.5^{\circ} \mathrm{C}$ with use of seawater/freshwater from two separate temperature-controlled $10 \mathrm{~m}^{3}$ reservoirs. Salinity in each tank was adjusted by peristaltic pumps (Longer Pumps BT600-2J, Hebai, China) 
which pumped an accurate amount of seawater to the freshwater tank inlet pipe for a thorough mixing.

Each tank was initially stocked with approximately 43 larvae/L; corresponding to near 2000 larvae/tank and reared until $30 \mathrm{DPH}$ at constant $24 \mathrm{~h}$ dimmed light conditions (i.e. 30-40 Lux at water surface) provided by LED light bulbs installed over each tank. From 4-9 DPH, larvae were fed a newly hatched unenriched Artemia nauplii (strain MC460, Artemia Systems INVE, Dendermonde, Belgium ) kept at $5^{\circ} \mathrm{C}$ after hatching for $2 \times 8 \mathrm{~h}$ by automatic dispensers each holding a suspension of Artemia in seawater programmed to feed every 20 min ensuring that live Artemia nauplii were present ad libitum in the tanks. From $10 \mathrm{DPH}$ and onwards larvae were similarly fed by EG Artemia nauplii (Artemia Systems INVE, Dendermonde, Belgium) enriched subsequent to hatching (+ $12 \mathrm{~h}$, i.e. nauplii stage II) for $24 \mathrm{~h}$ with one of two lipid emulsions based on either sunflower oil (SFO) or linseed oil (LO) and supplemented with olive oil (for obtaining similar levels of 18:1n-9, OA). The two emulsions were formulated to differ in composition of primarily LA and ALA FAs (Table 1). In both experimental emulsions a vitamin premix $\left(40 \mathrm{~g} \mathrm{~kg}^{-1}\right)$ and soy lecithin as an emulsifier $\left(70 \mathrm{~g} \mathrm{~kg}^{-1}\right)$ were added (BioMar, Tech Centre, Brande, Denmark) (Table 1). Organic sunflower oil and linseed oil were commercially available products; olive oil was highly refined and obtained from Croda Chemicals Europe, Snaith, UK.

The experiment was carried out in a triplicate set-up with 3 tanks per feed type at 3 salinities; i.e. 0 ppt; 5-6 ppt; 10-11 ppt equalling a total of $3 \times 3 \times 2$ (18) tanks. An additional group of larvae reared at 0 ppt salinity on EG Artemia enriched by a commercial DHA Selco (Artemia Systems INVE, Dendermonde, Belgium) was used as an experimental control.

Oxygen saturation and temperature were monitored daily by a hand-held Oxyguard meter from Oxyguard, Birkerød, Denmark. During the experiment, oxygen saturation was $88-94 \%$ (i.e. $8.8 \pm 1.3$ $\left.\mathrm{mg} \mathrm{L^{-1 }}\right)$ and temperature $\left(17.5 \pm 0.6^{\circ} \mathrm{C}\right)$.

The total flow rate of either freshwater or fresh and seawater was kept at approximately 11-12 $\mathrm{L} \mathrm{h}^{-1}$ tank $^{-1}$ and checked/adjusted twice daily and salinity in tanks was measured by a refractometer. On a daily basis the bottom of each tank was vacuum-cleaned for feed remaining, dead Artemia and dead larvae and collected in a bucket. The number of dead larvae per tank day ${ }^{-1}$ was then counted and registered.

The entire experiment and procedures were approved by the ethical committee at DTU Aqua. 


\subsection{Confinement mortality}

At the end of the experiment all remaining larvae were gently and slowly siphoned from the bottom outlet from each rearing tank by emptying the tanks through a pvc pipe into a submerged net. Larvae were then without air exposure transferred to a 20 × $20 \mathrm{~cm}$ wide plastic tray with a $2 \mathrm{~cm}$ water level (same salinity as in the rearing tank) and a light exposure of 500 Lux by a LED lamp. Larvae motility was observed for $5 \mathrm{~min}$ and subsequent mortality defined as larvae without movement by touch of a set of tweezers was then registered as dead. Total number of larvae was counted. After evaluation all fish were killed by an overdose of benzocaine.

\subsection{In vivo incubation with labelled ${ }^{14} \mathrm{C}$ fatty acids}

Larval capability to incorporate unsaturated FA into total lipids under the different dietary and salinity regimes was studied by in vivo radio tracing of ${ }^{14} \mathrm{C}$ fatty acids. More specifically, in the present study the method described by Reis et al. (2014) was adapted to determine the in vivo dynamic of incorporation of 5 different radiolabelled FA into pikeperch larvae total lipids, including the C18 FA precursors $(18: 2 n-6 ; 18: 3 n-3)$ particularly abundant in the assayed vegetable oils of the experimental diets, and also their main LC-PUFA physiologically active derivatives (20:4n-6, 20:5n-3 and 22:6n-3) present in the control diet.

Thirty non-fed larvae per tank (12 h feed deprived) at an age of $20 \mathrm{DPH}$ were sampled from the 6 different rearing conditions (i.e. SFO and LO groups; 0, 5, 10 ppt salinity) in addition to larvae from the DHA Selco control group at 0 ppt salinity. Larvae were incubated in flat-bottom tissue culture plates (10 larvae per plate) provided with gentle stirring for $5 \mathrm{~h}$, with $0.2 \mu \mathrm{Ci}(0.3 \mu \mathrm{M})$ of ${ }^{14} \mathrm{C}$ labelled FA including LA, ALA (PerkinElmer Inc., Waltham, Massachusetts, USA), ARA, EPA and DHA (American Radiolabelled Chemicals Inc., St. Louis, Missouri, USA). Larvae were incubated by triplicate in the same water, temperature and salinity as provided in the different experimental larval rearing conditions. The substrates were directly added to the incubation water. For each dietary and salinity treatment a group of 30 larvae incubated without ${ }^{14} \mathrm{C}$ FA were also assessed for fatty acid composition. In order to determine the radioactivity incorporated into whole larvae, an aliquot of $0.1 \mathrm{mg}$ of corresponding total lipid (TL) extracts from each sample were transferred to a scintillation vial. Radioactivity was quantified in a RackBeta 1214 liquid scintillation $\beta$-counter (LKB, Wallac, USA). Results in dpm were transformed into pmol mg protein $^{-1} \mathrm{~h}^{-1}$ taking into account the specific activity of each substrate, and sample TL and protein contents (Lowry et al., 1951). 


\subsection{Growth performance, survival and analytical samplings}

Representative samples of Artemia were sampled at 12 and 24 DPH for dry weight, and FA composition. At 15, 20, 25 and $30 \mathrm{DPH}, 25-35$ larvae per tank were sampled and weighed (mg w.w. ind $^{-1}$ ) for specific growth rate calculation (SGR) according to the formula:

$\operatorname{SGR}\left(\% \mathrm{day}^{-1}\right)=100 x(\ln w . w . f-\ln w . w . i) t^{-1}$,

where $\ln$ w.w. $f, i=$ the natural logarithm of the final and initial wet weight, $t=$ time (days),

A random subsample of 10 larvae per replicate was used for FA composition. Additionally, 10 and 20 larvae per tank were sampled at $30 \mathrm{DPH}$ for measurement of prostaglandin $\mathrm{PGE}_{2}$ and $\mathrm{PGE}_{3}$, and digestive enzymatic activities, respectively.

All above larval samples were sedated with benzocaine and immediately frozen at $-80^{\circ} \mathrm{C}$. Additional 20 larvae per tank were also taken at the end of the experimental period for skeleton morphogenesis and mineralization by staining. These larvae were sedated, fixed and stored in $10 \%$ phosphate buffered formaldehyde until analysis. Finally, for relevant genes involved in the skeletal system and organ development 10 larvae per replicate were sedated and stored in RNA later overnight at $4^{\circ} \mathrm{C}$ and then frozen at $-80^{\circ} \mathrm{C}$ until analysis.

Survival was estimated based on the approximate number of larvae inserted at $1 \mathrm{DPH}$ and total number of larvae collected after the confinement study at $30 \mathrm{DPH}$. Percent survival did not include larvae sampled during the experiment.

\subsection{Fatty acid analysis}

FA analysis of Artemia and larvae was done according to previously described (Lund et al., 2014). Briefly, lipids were extracted by a chloroform/methanol mixture, (2:1, v/v) (Folch et al., 1957) and $40 \mu \mathrm{L}\left(1 \mathrm{mg} \mathrm{mL}{ }^{-1}\right)$ of an internal 23:0 FAME standard from Sigma Aldrich was added. Larval samples (10 larvae per replicate) were homogenized by a Tissue Tearor probe diameter $4.5 \mathrm{~mm}$, Biospec Products, Inc; Bartlesville, USA, while Artemia samples were sonicated in an ultrasonic cleaner (Branson 2510, Hampton, New Hampshire) for $30 \mathrm{~min}$ in ice water. All samples were allowed standing for $24 \mathrm{~h}$ in $-20^{\circ} \mathrm{C}$ followed by centrifugation. The supernatant was subsequently transferred to clean GC vials and allowed drying out in a Pierce, reacti-therm heating module at $60^{\circ} \mathrm{C}$, under a continuous flow of nitrogen. Trans esterification of the lipids was done by addition of $1 \mathrm{~mL}$ of acetyl chloride in methanol (40:50:10, HPLC quality) at $95^{\circ} \mathrm{C}$. The fatty acid methyl esters were analyzed by gas chromatography-mass spectrometry (GC-MS). Peaks on a given 
chromatogram were identified by comparison with the retention time of a commercial mix of a known FAME standard, SUPELCO 18919 (4:0-24:0), from SIGMA (St. Louis, MO, USA). Peaks were quantified by means of the target response factor of the fatty acids and 23:0 as internal standard. Fatty acid concentrations were calculated (MSD Chemstation Data Analysis, G1710FA) based on the quantified peaks of the standard series and the samples as well of dry weight of prey and larvae and expressed as ng sample ${ }^{-1}$. A total of 34 fatty acids were analyzed, but only the most relevant are shown..

\subsection{Digestive enzymes}

Larval samples (except for Control Selco larvae, i.e. not analysed) were thawed and the heads and tails were removed to isolate the digestive segment on a glass maintained on ice $\left(0^{\circ} \mathrm{C}\right)$; the stomach region was then separated from the intestinal segments. Pooled samples from each tank were homogenized in 10 volumes (v/w) cold distilled water. Assays of cytosolic peptidase and leucine alanine peptidase (leu-ala) were performed following the method of Nicholson and Kim (1975) using leucine-alanine (Sigma-Aldrich, St. Louis, MO, USA) as substrate. Alkaline phosphatase (AP, ubiquitously present in larvae) and aminopeptidase $\mathrm{N}$ (AN, an enzyme of the brush border membrane), were assayed according to Bessey et al. (1946) and Maroux et al. (1973) using pnitrophenyl phosphate and L-leucine p-nitroanalide (Sigma-Aldrich) as substrates, respectively.

Pepsin was assayed by the method of Worthington (1982) modified by Cuvier-Péres and Kestemont (2002). Trypsin and amylase activities were assayed according to Holm et al. (1988) and Metais and Bieth (1968) respectively, such as described by Gisbert et al. (2009). Bile salt-activated lipase activity was assayed following the method of Iijima et al. (1998) modified by Gisbert et al. (2009) using p-nitrophenyl myristate as substrate. Protein was determined using the Bradford (1976) procedure. Enzyme activities are expressed as specific activities ( $\mathrm{U}$ or $\mathrm{mU} \mathrm{mg}$ protein ${ }^{-1}$ ).

\subsection{Quantitative LCMS/MS analysis PGE2 / PGE3}

Larval samples were analyzed by Cayman Chemical Company, Ann Arbor Michigan, USA. Fish larvae were thawed on wet ice prior to transferring to preweighed $2 \mathrm{~mL}$ Precellys soft tissue homogenizing tubes each containing $1.4 \mathrm{~mm}$ ceramic beads. Net wet weight of the samples was then calculated. Homogenization buffer $(0.1 \mathrm{M}$ potassium phosphate, $\mathrm{pH} 7.0$ containing $1 \mathrm{mM}$ EDTA and $10 \mu \mathrm{M}$ indomethacin), $1 \mu \mathrm{L}$ per mg wet tissue, was added to each vial. Samples were then homogenized in a Precellys Evolution tissue homogenizer at $5800 \mathrm{rpm}$ for 2 cycles of $15 \mathrm{~s}$ 
each. Samples were subsequently spun for $15 \mathrm{~min}$ on an Eppendorf centrifuge. A $200 \mu \mathrm{L}$ aliquot of supernatant from each sample was pipetted into a 96 deep well plate, spiked with $50 \mu \mathrm{L}$ of internal standard (1 ng mL PGE ${ }_{2}-\mathrm{d}_{4}{ }^{-1}$ ), diluted with $200 \mu \mathrm{L}$ of deionized water and vortexed thoroughly prior to solid phase extraction. Due to the presence of endogenous $\mathrm{PGE}_{2}$ and $\mathrm{PGE}_{3}$ calibrators were prepared in the homogenization buffer. External calibrators were prepared at ten concentrations over the range from $9.77 \mathrm{pg} \mathrm{mL}^{-1}$ to $5000 \mathrm{pg} \mathrm{mL}^{-1}$ by serial dilutions of a $100 \mathrm{ng} \mathrm{mL}^{-1}$ stock solution of $\mathrm{PGE}_{2}$ and $\mathrm{PGE}_{3}$ with homogenization buffer. $200 \mu \mathrm{L}$ of each calibrator solution was spiked with $50 \mu \mathrm{L}$ of internal standard and diluted with $200 \mu \mathrm{L}$ deionized water prior to extraction. Solid phase extraction was performed on Waters Oasis MAX microelution plates. Plate wells were conditioned with $200 \mu \mathrm{L}$ of acetonitrile followed by $25 \%$ acetonitrile in water. A volume of $450 \mu \mathrm{L}$ of sample or calibrator was added to the SPE plate and then the wells were washed with $200 \mu \mathrm{L}$ of $25 \%$ acetonitrile in water followed by $200 \mu \mathrm{L}$ of $100 \%$ acetonitrile. Samples were eluted into $25 \mu \mathrm{L}$ of a trapping solution (10\% glycerol in water) using $25 \mu \mathrm{L}$ of $50: 50$ acetonitrile/IPA $+5 \%$ formic acid. Prior to mass spectrometry, samples $(25 \mu \mathrm{L})$ were chromatographed on an Acquity UPLC equipped with a Waters BEH C8 (Milford Massachusetts, USA) / $100 \mathrm{~mm}$ x $2.1 \mathrm{~mm}, 1.6 \mu \mathrm{m}$ column at $25^{\circ} \mathrm{C}$. The flow rate was set to $400 \mu \mathrm{L} \min ^{-1}$ and mobile phase A was water $+0.1 \%$ formic acid and mobile phase $\mathrm{B}$ was acetonitrile $+0.1 \%$ formic acid. A gradient of $15 \%-50 \%$ mobile phase B over 12 min was used followed by a $1 \mathrm{~min}$ hold at $50 \% \mathrm{~B}$. The mass spectrometer was a Waters TQ-Su triple quadrupole (Milford Massachusetts, USA) set to run in negative electrospray ionization mode. The transitions for analytes and Internal Standard were tuned by infusion of $10 \mu \mathrm{g} \mathrm{mL} \mathrm{L}^{-1}$ solutions of the pure materials in 1:1 acetonitrile/water at $5 \mu \mathrm{L} \mathrm{min}{ }^{-1}$ into a mobile phase of $50 \% \mathrm{~B}$ at $400 \mu \mathrm{L} \mathrm{min}^{-1}$. The transitions used for quantitation were: $\mathrm{PGE}_{2}$ $351=>315, \mathrm{PGE}_{3} 349=>269$, and $\mathrm{PGE}_{2}-\mathrm{d}_{4} 355=>319$. The relative response ratio of analytes to internal standard was used for quantitation. Extraction recovery was determined to be $>90 \%$ for both analytes and calibrator linearity was $>0.999$ for both analytes over the calibration range. Precision of the method was tested by a LLOQ (10 $\left.\mathrm{pg} \mathrm{mL}^{-1}, \mathrm{n}=6\right)$ on two separate days using a mixture of $\mathrm{PGE}_{2}$ and $\mathrm{PGE}_{3}$ in buffer. \%RSD for $\mathrm{PGE}_{2}$ was $10.9 \%$ on day 1 and $13.3 \%$ on day 2 and $\mathrm{PGE}_{3}$ was $15.1 \%$ on day 1 and $13.3 \%$ on day 2 .

\subsection{Larval skeleton anomalies and gene expression}

Fixed 30 DPH pikeperch larvae (20 per replicate) were stained with alizarin red to evaluate the skeletal anomalies and vertebral mineralization following methods (Izquierdo et al., 2013) modified from previous studies (Vandewalle et al., 1998). Larvae were immediately photographed and 
examined for the occurrence of skeletal anomalies following Boglione et al. (2001) skeletal anomalies classification. The different regions of the vertebral column were divided according to Boglione et al. (2001). Vertebrae were numerated from 1 to 24 using Roman numerals in a cranial to caudal direction. The effects of the different salinities and $n-3 / n-6$ dietary contents on axial skeleton mineralisation were evaluated considering the total number of completely mineralised vertebral bodies within a larval size class (standard length).

Total RNA from larvae samples (10 larvae per replicate, average weight per sample $60 \mathrm{mg}$ ) was extracted using the RNeasy Mini Kit (Qiagen, Hilden, Germany). Total body tissue was homogenised using the TissueLyzer-II (Qiagen) with QIAzol lysis reagent (Qiagen). Samples were centrifuged with chloroform for phase separation $\left(12000 \mathrm{~g}, 15 \mathrm{~min}, 4^{\circ} \mathrm{C}\right)$. The upper aqueous phase containing RNA was mixed with $75 \%$ ethanol and transferred into an RNeasy spin column where total RNA bonded to a membrane and contaminants were washed away by RW1 and RPE buffers (Qiagen). Purified RNA was eluted with $30 \mu \mathrm{L}$ of RNase-free water. The quality and quantity of RNA were analysed using the NanoDrop 1000 Spectrophotometer (Thermo Scientific, Wilmington, DE, USA). Synthesis of cDNA was conducted using the iScript cDNA Synthesis Kit (Bio-Rad, Hercules, CA, USA) according to manufacturer's instructions in an iCycler thermal cycler (BioRad). Primer efficiency was tested with serial dilutions of a cDNA pool (1, 1:5, 1:10, 1:15, 1:20 and 1:25). Product size of the real-time $\mathrm{q}$ PCR amplification was checked by electrophoresis analyses using PB322 cut with HAEIII as a standard. Real-time quantitative PCR was performed in an iQ5 Multicolor Real-Time PCR detection system (Bio-Rad) using $\beta$-actin as the house-keeping gene (i.e. others were tried, but $\beta$-actin was chosen due to its stability) in a final volume of $20 \mu \mathrm{L}$ per reaction well, and $100 \mathrm{ng}$ of total RNA reverse transcribed to complementary cDNA. Each gene sample was analysed once per gene. The PCR conditions were the following: $95^{\circ} \mathrm{C}$ for $3 \mathrm{~min} 30 \mathrm{sec}$ followed by 40 cycles of $95^{\circ} \mathrm{C}$ for $15 \mathrm{sec}, 61^{\circ} \mathrm{C}$ for $30 \mathrm{sec}$, and $72^{\circ} \mathrm{C}$ for $30 \mathrm{sec} ; 95^{\circ} \mathrm{C}$ for $1 \mathrm{~min}$, and a final denaturing step from $61^{\circ} \mathrm{C}$ to $95^{\circ} \mathrm{C}$ for $10 \mathrm{sec}$. Data obtained were normalised and the Livak method $(2-\Delta \Delta \mathrm{Ct})$ used to determine relative mRNA expression levels. Pikeperch specific gene primers were designed after searching the NCBI nucleotide database and using the Oligo 7 Primer Analysis software (Molecular Biology Insights, Cascade, CO, USA). Detailed information on primer sequences and accession numbers is presented in Table 2.

\subsection{Statistics}


A two-way ANOVA in Sigma Plot Ver. 13 was used to compare larval wet weight, FA composition, incorporation of radioactivity into total larval lipids, enzymatic activity, degree of deformities, gene expression, stress confinement mortality and eicosanoid activity using diet and salinity as fixed factors. For the incorporation of radioactivity into total larval lipids, the statistical analyses were performed using the SPSS 21.0 software package (IBM Corp., New York, USA) for Windows. Prior to analysis normality and homogeneity of data were confirmed within treatment groups. A Tukey HSD test was used to determine significance of mean differences $(\mathrm{P}<0.05)$ between the treatment groups where applicable. If no interaction between factors (diet and salinity) in the outcome of the two-way ANOVA, a further one-way ANOVA and Tukey's HSD test were used to determine any significant differences. A Holm Sidak all pairwise multiple comparison of means test was applied for testing significance of mean differences $(\mathrm{P}<0.05)$ between the treatment groups where applicable. Each value is the mean \pm standard deviation (SD) from the analysis of triplicate replicates except where otherwise stated. Percent data were arcsine transformed prior to analysis.

\section{Results}

\subsection{Survival, growth and confinement test}

Some mortality was observed in most tanks after transfer of larvae to the experimental facilities within the first 5 days after hatching, but no significant correlation with diet or salinity $(\mathrm{P}>0.32)$ was found. Two types of cannibalism $(1,2)$; were observed in all tanks starting from 17 DPH until the end of the study; (1) prey partly ingested; (2) whole prey swallowed. Final survival at $30 \mathrm{DPH}$ (data not shown) was not significantly different $(\mathrm{P}=0.652)$ among experimental groups and ranged between 9 and 12\%. An apparent trend for a decrement of SFO30 DPH larval growth with increasing salinity and the opposite trend applying for LO diet, however dietary or salinity regime did not cause any significant differences in mean wet weight of larvae at 15, 20, 25 or 30 DPH (Fig. 1), the mean weight at $30 \mathrm{DPH}$ ranging from $20-33 \mathrm{mg}$ in a wet weight basis. Overall, growth from 15-30 DPH calculated as SGR was not significantly different between groups $(\mathrm{P}=0.592)$ and varied from 11.6-16.2\% among experimental groups including the control.

Confinement by gently transfer of surviving larvae from each experimental tank into a white tray with limited water volume and exposed to a strong light intensity at $30 \mathrm{DPH}$ caused high larval mortality in both experimental dietary SFO and LO groups. Subsequent to transfer, larvae in both 
groups reacted by erratic behavior and most larvae died within $30 \mathrm{sec}$ irrespectively of salinity. In the control group swimming behavior was similarly affected but erratic movements were less and mortality much lower even after 5 min of exposure (Fig. 2).

\subsection{FA composition of Artemia and larvae during development}

FA content of Artemia reflected the dietary composition of the emulsions (Table 3). LA in SFO enriched Artemia was about twice the content in LO enriched Artemia $(\mathrm{P}<0.001)$. Despite ALA is a major fatty acid in unenriched Artemia, its content was significantly higher in Artemia enriched by use of LO emulsion $(\mathrm{P}<0.001)$, constituting $42 \%$ of the total fatty acids (\% TFA) versus $32 \%$ in SFO enriched Artemia and $25 \%$ in DHA Selco enriched Artemia. Consequently, total n-3 content was the highest in LO Artemia and the n-3/n-6 ratio, 2.7 times higher in LO Artemia than in SFO Artemia. EPA and DHA content was 5.5\% and 6.5\% (\% TFA) in the DHA Selco enriched Artemia, respectively, while EPA content in SFO and LO Artemia was some 1.7\% ( $<<0.001)$. DHA was not found in Artemia from both experimental groups. The above FA differences in Artemia influenced significantly on larval tissue FA composition of LA and ALA at both 25 and 30 DPH and affected overall n-6 and n-3 PUFA content. Thus, larval FA composition mirrored the differences in Artemia composition (Table 4).

FA differences became more pronounced along with the growth of the larvae and the duration of the experiment. Five days after introducing the different diets (at DPH 15, Table 4) tissue content of LA was significantly higher in SFO fed larvae than in LO larvae $(\mathrm{P}<0.001)$. ALA tissue content was similar between the experimental groups apart in larvae from the LO-10 ppt salinity group, where its content was significantly higher $(\mathrm{P}<0.001)$ than larvae in any other groups except for those from the LO-5 ppt salinity. In addition, DHA content in LO-10 ppt larvae was significantly lower $(\mathrm{P}<0.001)$ than in larvae from the LO-0 ppt and SO-0 ppt groups. At 25 DPH (Table 4), we found no significant interacting effect of salinity $(\mathrm{P} \geq 0.156)$. Results on LA content between larvae from the SFO and LO groups were similar to those from $15 \mathrm{DPH}$, thus significantly higher in SFO fed larvae than in LO larvae $(\mathrm{P}<0.001)$. On the contrary, ALA content was not significantly different between groups $(\mathrm{P}=0.059)$. DHA was $6-10 \%$ of TFA, which was only half the larval content at 15 $\mathrm{DPH}$ with no significantly differences between experimental dietary groups $(\mathrm{P}=0.184)$. In contrast, the DHA level in the DHA Selco larval control group was 17\% TFA. At the final sampling point at $30 \mathrm{DPH}$ (Table 4), results revealed no interacting effect of salinity $(\mathrm{P} \geq 0.457)$; similarly to $25 \mathrm{DPH}$. Tissue LA content was similar to the previous sampling periods, and for all salinities assayed 
significantly higher $(\mathrm{P}<0.001)$ in SFO-larvae than in groups reared on the LO diet. On the contrary, ALA content was significantly higher $(\mathrm{P}<0.001)$ in all three salinity groups fed the LO diet than in those fed the SFO diet. DHA tissue content in larvae for both dietary experimental groups was some 4-7\% TFA, and differed from the DHA Selco control larvae, for which DHA content was $16 \%$ of TFA.

\subsection{Tissue incorporation of labelled ${ }^{14} \mathrm{C}$ fatty acids}

Results of the in vivo incubation with ${ }^{14} \mathrm{C} 18$ and ${ }^{14} \mathrm{C} 20-22$ PUFAs substrates revealed no significant differences in larval incorporation of radioactivity into total lipids comparing the 2 experimental diets (SFO or LO), but a significant effect of rearing salinity (Table 5). Thus, larvae reared in freshwater (at 0 ppt) incorporated more ${ }^{14} \mathrm{C} \quad 18: 2 \mathrm{n}-6$ in total lipids than larvae reared at $5 \mathrm{ppt}$ salinity, but not different from larvae reared at 10 ppt. Similarly, for 20:4n-6 and for the n-3 LCPUFA 22:6n-3, the highest incorporation was observed at 0 ppt, differing significantly from larvae reared at 5 and10 ppt. The average incorporation pattern of radioactivity into larval tissues independently of salinity and dietary rearing conditions was $20: 5 n-3>20: 4 n-6>18: 2 n-6=18: 3 n-3$ $=22: 6 n-3$ (Table 6).

\subsection{Eicosanoids}

Prostaglandin tissue levels $\mathrm{PGE}_{2}$ and $\mathrm{PGE}_{3}$ revealed no effects of dietary treatment, but a significant effect of salinity (Table 7). $\mathrm{PGE}_{2}$ and $\mathrm{PGE}_{3}$ content was significantly higher for larvae reared at 0 ppt (including the control group) than for larvae reared at 5 or 10 ppt. $\mathrm{PGE}_{2}$ and $\mathrm{PGE}_{3}$ levels were similar for larvae at 5 or $10 \mathrm{ppt}(\mathrm{P}=0.594 ; \mathrm{P}=0.393$, respectively).

\subsection{Digestive enzymatic activity}

At $30 \mathrm{DPH}, 4$ of the 7 analysed digestive enzymes displayed a significant difference, while no differences were observed in activity of lipase, Leu-ala or amylase. Pepsin activity was lower in larvae from treatment LO-10 ppt salinity whereas no pepsin activity was detected for larvae from the experimental groups SFO-5 ppt, LO-5 ppt and SFO-10 ppt (Table 8). Independently of dietary treatment, aminopeptidase $(\mathrm{N})$ activity was highest for larvae reared at $10 \mathrm{ppt}(\mathrm{P}<0.01)$, as so was trypsin activity $(\mathrm{P}<0.05)$ in larvae fed the SFO diet, which was not affected by salinity. Data also revealed a significantly higher $(\mathrm{P}<0.05)$ activity of alkaline phosphatase (AP) in larvae for treatment SFO-10 ppt. Regardless of diets, amylase activity tended to increase in larvae exposed to10 ppt salinity, although without statistical differences. 


\subsection{Skeleton anomalies and gene expression}

Of the 17 skeletal anomaly typologies observed, only 4 were significantly affected by the different treatments (Table 9). There was a general high incidence of cranial anomalies, particularly in maxillary bones (58-83\% population), and a low incidence of vertebral anomalies (Table 9). The lowest $(\mathrm{P}<0.05)$ incidences of severe and maxillary bone anomalies were found in fish reared at 0 ppt, regardless of the dietary fatty acid profile, whereas an increase in salinity lead to a higher incidence of this type of anomalies. Particularly, pikeperch fed SFO diet and reared at 5 or $10 \mathrm{ppt}$ and those fed LO diet and reared at $5 \mathrm{ppt}$ showed the significantly highest incidence of maxillary bone anomalies (Table 9). Also the two-way ANOVA showed the effect of salinity on the results, while there was no significant effect from the diets (Table 9). No differences were found in degree of mineralization according to the size of the larvae (data not shown). Despite the lack of significant differences in the expression of twist 2 amongst the different treatments, pikeperch fed SFO diet and reared at $10 \mathrm{ppt}$ and those fed LO diet and reared at $5 \mathrm{ppt}$ showed approximately doubled expression in twist2, than fish reared under the other conditions. Furthermore, results from the twoway ANOVA regarding expression of twist 2 showed interaction between salinity and the diets (Table 10). No significant differences or specific tendencies were found in alp or mef $2 c$ expression.

\section{Discussion}

Pikeperch larvae were exposed to different salinities and diets low in LC-PUFA by enrichment of Artemia with emulsions rich in vegetable oils (VO). The main FA constituents of vegetable sunflower oil (SFO) and linseed oil (LO); 18:2n-6 and 18:3n-3 respectively, significantly affected larval tissue FA content and gave rise to overall differences in n-6 and n-3 PUFAs content. In fish larvae, only very few studies have examined FA metabolism combining the influence of ambient salinities and diets consistently different in LA and ALA along the ontogeny with an in vivo ${ }^{14} \mathrm{C}$ PUFA incubation assay. By using direct incubation with $0.2 \mu \mathrm{Ci}(0.3 \mu \mathrm{M})$ of ${ }^{14} \mathrm{C}$ PUFAs we demonstrated for the first time in pikeperch larvae that, regardless of the environmental salinity or dietary regime, larvae possess a marked capacity to incorporate 20:5n-3 and 20:4n-6 compared to the other PUFAs assayed (22:6n-3, 18:3n-3 and 18:2n-6). In fact, EPA was by far the most incorporated PUFA among the tested substrates followed by ARA, while LA, ALA and DHA were less and similarly incorporated. This could either indicate a physiological need for EPA and ARA or a higher affinity for incorporation and esterification of C20 LC-PUFA into tissue, which need further studies as DHA would normally be regarded as the limiting most essential FA in pikeperch 
and other fish larvae (Watanabe, 1993; Takeuchi, 1997; Lund et al., 2014). This dynamic of incorporation should be particularly taken into account during enrichment protocols, considering that DHA must compete for incorporation with EPA or even with 18:3n-3, which is naturally abundant in the Artemia. Additionally, and for LA and ARA we observed that more radioactivity was incorporated into total lipids under freshwater conditions ( $0 \mathrm{ppt})$ as compared to salinity gradients of 5 and 10 ppt. These results seem to agree well with the analysed fatty acid profiles of larvae at $15 \mathrm{DPH}$ and fed the LO diet at $10 \mathrm{ppt}$ salinity (LO-10). Thus, this group had relatively higher tissue levels of 18:3n-3 and lower levels of DHA, indicating that a combination of diets rich in n-3 C18 PUFA and 10 ppt salinity do not favour LC-PUFA incorporation, neither synthesis as previously described for Chirostoma estor (Fonseca-Madrigal et al., 2012). In addition, in this case, salinity may have more influence on pike perch larval lipid metabolism during early ontogenetic development (at $15 \mathrm{DPH}$ ) than at 25-30 DPH, as LA, ALA, EPA and DHA tissue content correlated with dietary levels at these sampling points, irrespective to salinity gradients.

$\Delta 6$ desaturase is the first rate limiting enzyme in LC-PUFA biosynthesis and according to bibliography, salinity may have variable effects on modulation and expression of $\Delta 6$ desaturase enzymatic activity and therefore fatty acid composition in different fish species. The bioconversion of linoleic acid to ARA and from linolenic acid to EPA and DHA involves desaturations at the $\Delta 6$ and $\Delta 5$ positions in the carbon backbone as well as an intermediate 2-carbon elongation step (Vagner and Santigosa, 2011). Replacing FOs by VOs diets rich in LA and ALA consistently resulted in increased $\Delta 6$ activity in several carnivorous anadromous/freshwater fishes as reviewed by Vagner and Santigosa (2011). In some vertebrates it has been generally accepted that LA and ALA may compete for $\Delta-6$ desaturase substrate necessary for the biosynthesis of n-3 and n- 6 LC PUFAs (Emery et al., 2013). Results presented here cannot totally rule out some effect of dietary regime (LA, ALA ratio), or environmental salinity on expression and in vivo activity of these enzymes. However, we observed no significant differences in larval tissue content of ARA, EPA and DHA (apart from the aforementioned DHA content for LO-10 at $15 \mathrm{DPH}$ ) throughout the successive sampling points along the ontogeny of pikeperch at DPH 15, 25 and 30. This was evident despite feeding either the LO diet rich in ALA or the SFO diet rich in LA which caused a gradual depletion of especially larval tissue DHA but also larval EPA and ARA, suggesting no - or limited (i.e. $15 \mathrm{DPH}$ ) - effects of diet or salinity on the conversion of C18 FA precursors into LCPUFA. 
Size of larvae and growth until $30 \mathrm{DPH}$ was consistent to results obtained in previous experiments performed with the use of live feed (Artemia) throughout the rearing period (Lund et al., 2014), but relatively lower (i.e. SGR 11-16\% day ${ }^{-1}$ ) than in trials with microdiets introduced from15 DPH and reared at 20-21 ${ }^{\circ} \mathrm{C}$ (Hamza et al., 2008; Lund et al., 2017, unpublished data, i.e SGR 21-24\% day ${ }^{-1}$ ). The enzymatic data provided no clear evidence as to the influence of salinity or diet. The observed low enzymatic pepsin activity at $30 \mathrm{DPH}$ and a higher trypsin activity for all larval groups suggest a limited activity of a functional stomach indicating a relatively slow growth by use of Artemia feeding and consequently a delay in process of morphogenesis. The larval control group reared at 0 ppt salinity on DHA Selco enriched Artemia was similar in size to larvae fed the LO and SFO enriched larvae, suggesting that LC-PUFA supplementation, VO based experimental emulsions ( $\mathrm{n}$ $3 / \mathrm{n}-6$ ratio) or salinity levels up to $10 \mathrm{ppt}$ has limited effects on growth at these ages.

Prior to the present experiment we tested the tolerance of first feeding pike perch larvae to several isosmotic salinity gradients and in none of them $10 \mathrm{ppt}$ seemed to affect growth and survival, while $>15$ ppt had a significant negative influence (unpublished results). In comparison, salinities of 10 ppt caused a 50\% reduction in growth rate in Eurasian perch ( $P$. fluviatilis) juveniles of $1.5-2 \mathrm{~g}$ initial body weight (Overton et al., 2008) while, in a study with Eurasian perch larvae, survival was significantly affected by salinity as only 2 individuals out of 344 larvae survived at 9.6 ppt (Bein and Ribi, 1994). This indicates a much higher salinity tolerance in pikeperch, despite that both species naturally inhabit same areas with various strengths of brackish water. We suggest that a main factor to explain a relatively slow growth in this experiment was a combination of lower rearing temperature $17.5^{\circ} \mathrm{C}$ vs $20-21^{\circ} \mathrm{C}$ (Hamza et al., 2008) and the use of Artemia as feed. Pikeperch larvae are able to digest and utilize microdiets from about 12-15 DPH and as a large quantity of amino acid is necessary for sustaining efficient protein synthesis in rapid growing fish larvae (Rønnestad et al., 1999), Artemia will most likely not provide optimal protein content and amino acid composition throughout the growth period (Helland et al., 2003). In the referred microdiet studies on pikeperch larvae by Hamza et al. $(2008,2012)$ a positive effect on elevated growth and development was additionally attributed to dietary levels of phospholipids independently of LC-PUFA levels. This effect has been reported in other species (Gisbert et al., 2005; Cahu et al., 2009; Olsen et al., 2014) suggesting that PUFAs provided as triacylglycerides in live enriched prey (Artemia) may have a growth limiting effect. This may further explain the similarity in larval growth between the experimental emulsions without LC-PUFAs and the commercial DHA Selco emulsion. In the present experiment, overall lipase activity was similar in 
larval groups and apparently not affected by the relative difference in an enrichment protocol based on triglycerides in the form of $18: 2 n-6$ or $18: 3 n-3$ as main FA constituents.

Though no effects on growth, larvae fed DHA Selco enriched Artemia had much elevated LCPUFA, especially DHA tissue content as compared with larvae reared on Artemia enriched by sunflower oil or linseed oil based emulsions. This likely explains a higher stress resistance as evidenced by less erratic swimming behavior and lower mortality (Fig. 2), when challenged to a combination of confinement and light intensity stressors. These results confirm previous findings on pikeperch larvae and observations of high stress sensitivity and mortality, when fed diets low or deficient in DHA and when exposed to salinity challenge tests at 20 ppt (Lund and Steenfeldt, 2011; Lund et al., 2014). Similarly, red drum (Sciaenops ocellatus) larvae reared on high DHA to EPA ratio of 3.8 and challenged to a salinity vitality test exhibited significant stress resistance as compared to larvae fed on lower DHA to EPA ratios (Brinkmeyer and Holt, 1998). Similar dietary effects of DHA with larvae of other marine fishes have been reported (Izquierdo et al., 1989; Takeuchi et al., 1991). Although the aim of the present study was not to define the exact nutritional requirement of LC-PUFAs or DHA to EPA ratio, results point out to the essentially and critical role of dietary DHA supplementation in pikeperch larval nutrition.

ARA and EPA are precursors of eicosanoids namely the 2- and 3- series prostanoids respectively, and the abundance of the two FAs in tissues determines the eicosanoid potency (Bransden et al., 2005). We found elevated prostaglandin levels of both $\mathrm{PGE}_{2}$ and $\mathrm{PGE}_{3}$ in larvae reared at $0 \mathrm{ppt}$ salinity compared with larvae reared at 5 or $10 \mathrm{ppt}$ salinity with no interaction effects and displaying similar tissue levels of ARA and EPA. Eicosanoids are known to be responsible for a range of physiological functions in fishes, such as modulating immune and neural function and homeostasis of osmoregulation, and controlling the stress response (Koven et al., 2001, 2003; Tocher, 2003). In mammals, systemic osmotic imbalances such as chronic salt loading and hydration stimulate renal prostaglandin production that facilitates salt excretion via complex pathways (Choe et al., 2006). Cyclooxygenase (COX) is the enzyme responsible for the initial ratelimiting conversion of arachidonic acid to prostaglandin G2. In killifish (Fundulus heteroclitus) an orthologue of mammalian COX2 has been found in chloride cells, where it may function in systemic and cellular osmoregulation (Choe et al, 2006). What seems to be evident from the present results is that the assayed increasing salinities reduced PGE2 and PGE3 production, which somehow might modify the osmoregulation homeostatic status of the larvae. However, it is to be examined if a similar functional response of salinity and osmoregulation exists in pike perch 
juveniles and the possible interactions between salinity, COX activity, levels of PGE prostaglandins, and stress response.

We observed a high incidence of skeletal anomalies affecting endochondral bones. In addition, an increase in salinity lead to a higher incidence of this type of skeletal anomalies in SFO larvae while a similar effect was observed for LO fed larvae at 5 ppt. Changes in environmental salinity may cause an osmoregulatory stress in fish (Deane et al., 2009). Even euryhaline teleosts require adaptive modifications in ion and osmoregulatory processes that may imply changes in blood $\mathrm{pH}$, plasma acid-base or ventilatory rates (Claiborne et al., 1994). These physiological reactions to compensate osmoregulatory stress may increase the risk of peroxidation and the subsequent proliferation of toxic oxidised compounds that induce apoptosis of mammalian bone cells and fish larvae (Izquierdo et al., 2013). Oxidative stress has been associated with particular anomalies in the cranium (Izquierdo et al., 2013), such as maxillary or dentary bones anomalies, skeletal elements that develop from a cartilaginous precursor. In the present study, an increase in salinity lead to a higher incidence of bone anomalies in SFO larvae, particularly in maxillary bones, that related well with the interaction between factors (salinity and diet) in twist2 expression (Table 10). On the one hand, chondrocyte ossification is regulated by twist genes that are expressed in mesenchymal cells in medaka (Oryzias latipes) and affect skull development in mice (Renn et al., 2006). Thus, overexpression of twist2 inhibits osteogenesis maintaining cells in a pre-osteoblast phenotype during osteoblast development (Renn and Winkler, 2009). Expression of the gene Runx2 is necessary for osteoblast differentiation (Bialek et al., 2004). Insufficient runx2 activity caused by overexpression of twist 2 gave rise to impaired skull formation (Kronenberg, 2004). In the present study, up-regulation of twist 2 was related to the increased incidence of skull anomalies in pikeperch reared at higher salinities (in the SFO diet), possibly due to the impairment of chondrocyte maturation as occurs in medaka. Despite not being significantly different, up-regulation of sox 9,5 in the same fish would promote chondrogenic differentiation to compensate the fail in chondrocyte maturation caused by twist 2 up-regulation. Sox 9 expression in cooperation with sox5 and sox6, is necessary for early chondrogenic differentiation and in humans, mutation of the sox $9 b$ gene leads to severe cranial defects.

The low incidence of anomalies related to vertebral bodies, an intra membranous type skeletal element, regardless salinity or dietary treatment, agree well with the similar expression of alp. Alp is a molecular marker of late mineralization of intra-membranous bones whose expression is markedly affected by EPA and DHA (Izquierdo et al., 2013; Saleh et al., 2013a,b). Therefore, the lack of 
significant differences in the LC-PUFA contents in $30 \mathrm{DPH}$ pikeperch fed SFO or LO Artemia agree well with the lack of differences in alp expression. Moreover, the control fish fed DHA enriched Artemia showed higher DHA and EPA body contents coinciding with the complete lack of vertebral anomalies. Mef $2 c$ expression was neither affected by salinity or dietary fatty acid profiles and was not related to the skeletal anomalies found in pikeperch. These results are in agreement with those obtained in other freshwater or marine species where mef $2 c$ expression was not affected by changes in dietary protein or lipid sources (Liland et al., 2015; Benedito-Palos et al., 2016). On the contrary, mef $2 c$ may be up-regulated by dietary PL ratio leading to hypertrophy of myotubes that could be the origin of vertebral anomalies (Overturf et al., 2016).

\section{Conclusions}

The obvious incorporation of all the ${ }^{14} \mathrm{C}$ substrates indicates the suitability of the complementary methodology used to study in vivo lipid metabolism of pikeperch larvae as also shown in newly hatched cephalopods and other marine organism's larvae (Reis et al., 2014, 2017). The present results showed a highest incorporation of EPA and ARA into pikeperch lipids, probably indicating a physiological need of this species for these FAs during its first stages of life or a higher affinity for incorporation and esterification of C20 PUFA. Nonetheless, future studies regarding esterificaction and elongase/desaturase patterns towards incubated C14 PUFA, should be performed in order to further elucidate FA metabolism by pikeperch larvae. Rearing salinity conditions up to $10 \mathrm{ppt}$ had no effects on growth or survival of larvae and no clear effects on digestive enzymatic activity, but affected endocrine hormonal prostaglandin production. Results indicate that lipid and FA metabolism could be modified in response to salinity changes and may involve a variety of regulatory endocrine processes in the developing fish larvae such as cortisol levels, hormone production and interactions and signal transductions, but further studies are required to clarify such regulatory processes. A detailed evaluation of the different types of skeleton anomalies as well as the expression of related molecular markers was conducted for the first time in the larval phases of this species. Our present research pointed out the high occurrence of anomalies in endochondral bones and the increased incidence at higher salinities. Finally, and although no exact nutritional requirement of LC-PUFA was defined, the results of this study suggest the essentiality and critical role of LC PUFA especially dietary DHA supplementation in pikeperch larval nutrition.

\section{Acknowledgements}


We like to thank Paul D. Kennedy, Cayman Chemical Company, Ann Arbor, Michigan USA for kindly assistance regarding prostaglandin $\mathrm{PGE}_{2}$ and $\mathrm{PGE}_{3}$ analyses and to AquaPri, Denmark for providing the larvae for the experiment.

\section{Funding}

The study has been supported under the framework of the European Union Seventh Framework Programme project DIVERSIFY (KBBE-2013-07 single stage, GA 603121) titled "Exploring the biological and socio-economic potential of new/emerging fish species for the expansion of the European aquaculture industry". Research on skeletal anomalies was partly funded by Agencia Canaria de Investigación, Innovación y Sociedad de la Información for a predoctoral grant for D. Dominguez for $\mathrm{PhD}$ studies (TESIS 2015010078). Covadonga Rodríguez belongs to the Institute of Biomedical Technologies (ITB) of the Canary Islands.

\section{Conflict of interest: "None".}

Ethics and animal welfare: The study has been conducted in accordance with national and international guidelines according to animal welfare ethics and approved. The ARRIVE guidelines for animal research studies have been followed.

Table 1. Dietary composition of the 2 experimental emulsions and a commercial DHA Selco control.

\begin{tabular}{|c|c|c|c|}
\hline Diet Ingredients (\%) & *DHA Selco & SFO & LO \\
\hline Linseed oil $^{\mathrm{a}}$ & & 0 & 68 \\
\hline Sunflower oil ${ }^{\mathrm{b}}$ & & 85 & 0 \\
\hline Olive oil ${ }^{\mathrm{c}}$ & & 4 & 21 \\
\hline Soy lecithin ${ }^{\mathrm{d}}$ & & 7 & 7 \\
\hline Vitamin Premix ${ }^{\mathrm{e}}$ & & 4 & 4 \\
\hline
\end{tabular}

${ }^{\text {abcde }}$ see Material and Methods section; *DHA Selco: a commercial control emulsion (INVE, Artemia Sy stems, Dendermonde, Belgium; composition: $60 \%$ fish oil, $33 \%$ moisture, $1 \%$ protein) 
Table 2. Sequences of primers used for gene expression analysis.

\begin{tabular}{ll}
\hline Gene & Nucleotide Sequence \\
\hline \multirow{2}{*}{ Alp } & F: 5'-GCTGTCCGATCCCAGTGTAA-3' \\
& R: 5'-CCAGTCTCTGTCCACACTGT-3' \\
Twist2 & F: 5'-CCCCTGTGGATAGTCTGGTG-3' \\
& R: 5'-GACTGAGTCCGTTGCCTCTC-3' \\
Mef2c & F: 5'-GCGAAAGTTTGGCCTGATGA-3' \\
& R: 5'-TCAGAGTTGGTCCTGCTCTC-3' \\
Sox9 & F: 5'-TCCCCACAACATGTCACCTA-3' \\
& R:5'-AGGTGGAGTACAGGCTGGAG-3' \\
\hline
\end{tabular}

Table 3. Total fatty acid content (TFA, $\mu \mathrm{g} \mathrm{g} \mathrm{dm}{ }^{-1}$ ) and main fatty acid content (\% TFA) of Artemia enriched with DHA Selco control; sunflower oil (SFO) emulsion or linseed oil (LO) emulsion (mean $\pm \mathrm{SD}, \mathrm{n}=2$ ).

\begin{tabular}{lccc}
\hline Diet & DHA Selco & \multicolumn{1}{l}{ SFO } & LO \\
\hline TFA $\left(\mu \mathrm{g} \mathrm{dm}^{-1}\right)$ & $239 \pm 122$ & $400 \pm 173$ & $247 \pm 107$ \\
\hline$F A$ & & & \\
16:0 & $10.8 \pm 0.5$ & $9.7 \pm 0.2$ & $9.5 \pm 0.4$ \\
$18: 0$ & $5.3 \pm 0.2^{\mathrm{a}}$ & $6.0 \pm 0.2^{\mathrm{b}}$ & $6.1 \pm 0.1^{\mathrm{ab}}$ \\
Total SFA & $18.9 \pm 1.5$ & $17.7 \pm 0.7$ & $17.5 \pm 0.7$ \\
16:1 (n-7) & $2.4 \pm 0.1^{\mathrm{b}}$ & $1.2 \pm 0.1^{\mathrm{a}}$ & $1.3 \pm 0.1^{\mathrm{a}}$ \\
18:1 (n-9) OA & $25.4 \pm 0.1$ & $25.3 \pm 0.1$ & $25.9 \pm 0.5$ \\
Total MUFA & $31.7 \pm 1.4$ & $27.7 \pm 0.3$ & $28.4 \pm 0.8$
\end{tabular}




\begin{tabular}{cccc}
$18: 2(\mathrm{n}-6)$ LA & $9.5 \pm 0.1^{\mathrm{b}}$ & $18.3 \pm 0.0^{\mathrm{c}}$ & $8.1 \pm 0.2^{\mathrm{a}}$ \\
$18: 3(\mathrm{n}-6)$ & $0.5 \pm 0.0$ & $0.5 \pm 0.0$ & $0.6 \pm 0.1$ \\
20:3 (n-6) & $0.1 \pm 0.2$ & $0.0 \pm 0.0$ & $0.0 \pm 0.0$ \\
20:4 (n-6) ARA & $1.2 \pm 0.4$ & $0.5 \pm 0.0$ & $0.6 \pm 0.1$ \\
Total (n-6) PUFA & $11.6 \pm 1.0^{\mathrm{b}}$ & $19.5 \pm 0.4^{\mathrm{c}}$ & $9.3 \pm 0.5^{\mathrm{a}}$ \\
18:3 (n-3) ALA & $24.6 \pm 1.0^{\mathrm{a}}$ & $32.0 \pm 0.8^{\mathrm{b}}$ & $41.5 \pm 0.6^{\mathrm{c}}$ \\
20:3 (n-3) & $1.3 \pm 0.1$ & $1.4 \pm 0.0$ & $1.6 \pm 0.1$ \\
20:5 (n-3) EPA & $5.5 \pm 0.1^{\mathrm{b}}$ & $1.7 \pm 0.2^{\mathrm{a}}$ & $1.6 \pm 0.2^{\mathrm{a}}$ \\
$22: 6(\mathrm{n}-3)$ DHA & $6.5 \pm 0.1^{\mathrm{b}}$ & $0.0 \pm 0.0^{\mathrm{a}}$ & $0.0 \pm 0.0^{\mathrm{a}}$ \\
Total (n-3) PUFA & $37.9 \pm 1.4^{\mathrm{a}}$ & $35.1 \pm 1.0^{\mathrm{a}}$ & $44.8 \pm 0.9^{\mathrm{b}}$ \\
DHA/EPA & $1.2 \pm 0.0^{\mathrm{b}}$ & $0.0 \pm 0.0^{\mathrm{a}}$ & $0.0 \pm 0.0^{\mathrm{a}}$ \\
$(\mathrm{n}-3) /(\mathrm{n}-6)$ & $3.3 \pm 0.2^{\mathrm{b}}$ & $1.8 \pm 0.3^{\mathrm{a}}$ & $4.8 \pm 0.4^{\mathrm{c}}$ \\
\hline
\end{tabular}

Values in a row followed by a different superscript are significantly different $(\mathrm{P}<0.05)$. 
Table 4. Total fatty acid content (TFA, $\mu \mathrm{g} \mathrm{g} \mathrm{dm}^{-1}$ ) and main fatty acid composition (\% TFA) of larvae at 15, 25 and 30 days post hatch (DPH) fed Artemia enriched with sunflower oil (SFO) or linseed oil (LO) at 3 different salinities (mean $\pm S D, n=3$ ). DHA Selco control, 0 ppt.

\begin{tabular}{|c|c|c|c|c|c|c|c|}
\hline \multirow{2}{*}{$\frac{\text { Diet }}{\text { Salinity }(p p t)}$} & \multirow{2}{*}{$\frac{\text { DHA Selco }}{0(\mathrm{n}=1)}$} & \multicolumn{3}{|l|}{ SFO } & \multicolumn{3}{|l|}{ LO } \\
\hline & & 0 & 5 & 10 & 0 & 5 & 10 \\
\hline & & \multicolumn{6}{|c|}{$15 \mathrm{DPH}$} \\
\hline TFA $\left(\mu \mathrm{g} \mathrm{g} \mathrm{dm}^{-1}\right)$ & 101.0 & $92.8 \pm 12.8$ & $106.0 \pm 18.8$ & $98.2 \pm 6.2$ & $110.4 \pm 29.6$ & $103.5 \pm 8.1$ & $114.5 \pm 18.1$ \\
\hline Total SFA & 23.6 & $23.0 \pm 1.2$ & $23.1 \pm 1.3$ & $23.8 \pm 1.1$ & $23.4 \pm 1.0$ & $23.2 \pm 0.4$ & $23.8 \pm 0.9$ \\
\hline Total MUFAs & 26.0 & $25.9 \pm 1.7$ & $26.1 \pm 2.3$ & $26.1 \pm 1.6$ & $26.8 \pm 2.4$ & $26.7 \pm 2.1$ & $28.0 \pm 1.9$ \\
\hline 18:2 (n-6) LA & 8.5 & $10.4 \pm 0.1^{\mathrm{b}}$ & $10.5 \pm 0.6^{\mathrm{b}}$ & $10.7 \pm 0.4^{\mathrm{b}}$ & $6.0 \pm 0.5^{\mathrm{a}}$ & $6.2 \pm 0.2^{\mathrm{a}}$ & $6.6 \pm 0.2^{\mathrm{a}}$ \\
\hline 20:4 (n-6) ARA & 1.6 & $1.3 \pm 0.1$ & $1.3 \pm 0.1$ & $1.3 \pm 0.1$ & $1.3 \pm 0.1$ & $1.3 \pm 0.1$ & $1.2 \pm 0.1$ \\
\hline Total (n-6) PUFA & 11.5 & $12.8 \pm 1.2^{\mathrm{b}}$ & $12.9 \pm 0.8^{\mathrm{b}}$ & $13.2 \pm 0.5^{\mathrm{b}}$ & $8.2 \pm 0.7^{\mathrm{a}}$ & $8.5 \pm 0.3^{\mathrm{a}}$ & $8.9 \pm 0.4^{\mathrm{a}}$ \\
\hline 18:3 (n-3) ALA & 13.6 & $12.6 \pm 0.5^{\mathrm{a}}$ & $14.2 \pm 0.6^{\mathrm{a}}$ & $14.4 \pm 1.7^{\mathrm{a}}$ & $15.8 \pm 2.5^{\mathrm{a}}$ & $16.5 \pm 2.2^{\mathrm{ab}}$ & $20.6 \pm 1.2^{\mathrm{b}}$ \\
\hline 20:5 (n-3) EPA & 5.4 & $3.1 \pm 0.2$ & $3.1 \pm 0.1$ & $3.1 \pm 0.2$ & $3.1 \pm 0.1$ & $3.3 \pm 0.2$ & $3.0 \pm 0.0$ \\
\hline 22:6 (n-3)DHA & 19.1 & $21.7 \pm 2.1^{\mathrm{b}}$ & $19.5 \pm 2.1^{\mathrm{ab}}$ & $18.2 \pm 2.8^{\mathrm{ab}}$ & $21.4 \pm 2.9^{\mathrm{b}}$ & $20.5 \pm 3.1^{\mathrm{ab}}$ & $14.3 \pm 1.3^{\mathrm{a}}$ \\
\hline Total (n-3) PUFA & 41.5 & $38.5 \pm 2.9$ & $37.9 \pm 2.9$ & $36.9 \pm 4.7$ & $41.5 \pm 5.6$ & $41.6 \pm 5.7$ & $39.3 \pm 2.5$ \\
\hline DHA/EPA & 3.5 & $6.9 \pm 0.7^{\mathrm{b}}$ & $6.3 \pm 0.4^{\mathrm{ab}}$ & $5.9 \pm 0.6^{\mathrm{ab}}$ & $6.9 \pm 0.7^{b}$ & $6.2 \pm 0.8^{\mathrm{ab}}$ & $4.8 \pm 0.4^{\mathrm{a}}$ \\
\hline$(n-3) /(n-6)$ & 4.2 & $3.0 \pm 1.5$ & $2.9 \pm 1.5$ & $2.8 \pm 1.1$ & $5.0 \pm 0.5$ & $4.9 \pm 0.9$ & $4.4 \pm 0.9$ \\
\hline TFA $\left(\mu \mathrm{g} \mathrm{g} \mathrm{dm}^{-1}\right)$ & 58.6 & $64.5 \pm 45.7$ & $40.7 \pm 13.7$ & $59.9 \pm 14.6$ & $64.6 \pm 20.8$ & $101.9 \pm 43.2$ & $81.2 \pm 33.1$ \\
\hline Total SFA & 24.4 & $25.2 \pm 0.6$ & $25.6 \pm 0.6$ & $24.9 \pm 0.5$ & $24.7 \pm 1.0$ & $24.9 \pm 2.1$ & $24.7 \pm 2.0$ \\
\hline Total MUFAs & 25.7 & $26.7 \pm 0.7$ & $26.2 \pm 0.5$ & $27.3 \pm 0.7$ & $28.5 \pm 1.2$ & $29.6 \pm 1.8$ & $28.9 \pm 4.5$ \\
\hline 18:2 (n-6) LA & 6.2 & $12.2 \pm 0.8^{\mathrm{b}}$ & $12.9 \pm 0.5^{\mathrm{b}}$ & $13.1 \pm 0.3^{\mathrm{b}}$ & $8.8 \pm 0.7^{\mathrm{a}}$ & $9.1 \pm 0.7^{\mathrm{a}}$ & $9.1 \pm 0.3^{\mathrm{a}}$ \\
\hline 20:4 (n-6) ARA & 2.4 & $1.5 \pm 0.1$ & $1.6 \pm 0.0$ & $1.4 \pm 0.1$ & $1.4 \pm 0.2$ & $1.2 \pm 0.1$ & $1.4 \pm 0.4$ \\
\hline Total (n-6) PUFA & 9.6 & $15.2 \pm 1.0^{\mathrm{b}}$ & $16.3 \pm 0.6^{\mathrm{b}}$ & $16.2 \pm 0.5^{\mathrm{b}}$ & $11.6 \pm 1.0^{\mathrm{a}}$ & $11.7 \pm 0.9^{\mathrm{a}}$ & $11.9 \pm 0.8^{\mathrm{a}}$ \\
\hline 18:3 (n-3) ALA & 13.9 & $17.9 \pm 1.7$ & $17.3 \pm 0.8$ & $19.4 \pm 0.9$ & $20.9 \pm 0.6$ & $22.5 \pm 2.9$ & $22.6 \pm 4.4$ \\
\hline 20:5 (n-3) EPA & 8.1 & $3.3 \pm 0.2$ & $3.7 \pm 0.1$ & $3.5 \pm 0.1$ & $3.4 \pm 0.0$ & $3.1 \pm 0.2$ & $3.4 \pm 0.5$ \\
\hline 22:6 (n-3)DHA & 17.1 & $10.0 \pm 2.3$ & $9.1 \pm 0.3$ & $7.1 \pm 0.9$ & $9.1 \pm 0.5$ & $6.4 \pm 2.3$ & $6.5 \pm 4.3$ \\
\hline Total (n-3) PUFA & 40.4 & $32.8 \pm 4.4$ & $31.9 \pm 1.2$ & $31.6 \pm 1.9$ & $35.2 \pm 1.2$ & $33.9 \pm 5.5$ & $34.5 \pm 9.3$ \\
\hline DHA/EPA & 2.1 & $3.1 \pm 0.9$ & $2.5 \pm 0.1$ & $2.0 \pm 0.2$ & $2.7 \pm 0.1$ & $2.1 \pm 0.7$ & $1.8 \pm 0.9$ \\
\hline \multirow[t]{2}{*}{$(n-3) /(n-6)$} & 42 & $2.2 \pm 1.0$ & $2.0 \pm 0.6$ & $2.0 \pm 0.1$ & $3.0 \pm 0.3$ & $2.9 \pm 1.8$ & $2.9 \pm 0.7$ \\
\hline & & \multicolumn{6}{|c|}{30 DPH } \\
\hline TFA $\left(\mu \mathrm{g} \mathrm{g} \mathrm{dm^{-1 } )}\right.$ & 45.1 & $51.7 \pm 20.7$ & $33.6 \pm 5.4$ & $49.0 \pm 13.0$ & $46.1 \pm 12.6$ & $36.3 \pm 7.7$ & $35.4 \pm 9.0$ \\
\hline Total SFA & 24.2 & $23.8 \pm 1.0$ & $22.6 \pm 0.7$ & $23.1 \pm 0.5$ & $24.5 \pm 1.6$ & $23.5 \pm 1.3$ & $23.6 \pm 0.7$ \\
\hline Total MUFAs & 25.6 & $28.0 \pm 1.5$ & $28.4 \pm 0.7$ & $26.8 \pm 1.0$ & $30.1 \pm 2.0$ & $30.1 \pm 1.0$ & $30.2 \pm 1.8$ \\
\hline 18:2 (n-6) LA & 6.4 & $15.9 \pm 0.5^{\mathrm{b}}$ & $16.9 \pm 0.2^{\mathrm{b}}$ & $15.8 \pm 0.8^{\mathrm{b}}$ & $8.7 \pm 0.1^{\mathrm{a}}$ & $8.7 \pm 0.3^{\mathrm{a}}$ & $8.5 \pm 0.1^{\mathrm{a}}$ \\
\hline $20: 4(n-6)$ ARA & 2.3 & $1.3 \pm 0.1$ & $1.2 \pm 0.1$ & $1.6 \pm 0.2$ & $1.2 \pm 0.3$ & $1.2 \pm 0.1$ & $1.2 \pm 0.2$ \\
\hline Total (n-6) PUFA & 9.8 & $18.9 \pm 0.7^{b}$ & $20.0 \pm 0.3^{\mathrm{b}}$ & $19.2 \pm 1.1^{\mathrm{b}}$ & $11.3 \pm 0.4^{\mathrm{a}}$ & $11.3 \pm 0.5^{\mathrm{a}}$ & $11.1 \pm 0.4^{\mathrm{a}}$ \\
\hline 18:3 (n-3) ALA & 11.5 & $17.1 \pm 2.0^{\mathrm{a}}$ & $18.9 \pm 0.5^{\mathrm{a}}$ & $17.5 \pm 0.9^{\mathrm{a}}$ & $25.9 \pm 2.2^{\mathrm{b}}$ & $24.1 \pm 1.3^{\mathrm{b}}$ & $25.2 \pm 1.1^{\mathrm{b}}$ \\
\hline $20: 5(n-3)$ EPA & 8.8 & $3.0 \pm 0.3$ & $3.1 \pm 0.2$ & $3.7 \pm 0.2$ & $3.0 \pm 0.5$ & $3.2 \pm 0.3$ & $3.2 \pm 0.3$ \\
\hline 22:6 (n-3)DHA & 16.4 & $7.1 \pm 1.8$ & $4.4 \pm 0.3$ & $6.0 \pm 1.2$ & $4.8 \pm 1.0$ & $5.1 \pm 0.8$ & $4.3 \pm 1.1$ \\
\hline Total (n-3) PUFA & 39.9 & $28.7 \pm 4.1^{\mathrm{ab}}$ & $28.0 \pm 1.0^{\mathrm{a}}$ & $28.9 \pm 2.3^{\mathrm{ab}}$ & $35.5 \pm 3.7^{\mathrm{b}}$ & $34.3 \pm 2.5^{\mathrm{ab}}$ & $34.6 \pm 2.6^{\mathrm{ab}}$ \\
\hline DHA/EPA & 2.1 & $2.4 \pm 0.6^{\mathrm{b}}$ & $1.4 \pm 0.1^{\mathrm{ab}}$ & $1.6 \pm 0.3^{\mathrm{ab}}$ & $1.6 \pm 0.1^{\mathrm{ab}}$ & $1.6 \pm 0.4^{\mathrm{ab}}$ & $1.3 \pm 0.2^{\mathrm{a}}$ \\
\hline$(n-3) /(n-6)$ & 4.1 & $1.5 \pm 0.1^{\mathrm{a}}$ & $1.4 \pm 0.5^{\mathrm{a}}$ & $3.2 \pm 0.7^{\mathrm{b}}$ & $1.4 \pm 0.5^{\mathrm{a}}$ & $3.0 \pm 1.0^{\mathrm{b}}$ & $3.1 \pm 0.6^{b}$ \\
\hline
\end{tabular}

Values in a row followed by a different superscript are significantly different $(\mathrm{P}<0.05)$ between experimental diets. 
Table 5. Incorporation of radioactivity into total lipid (pmol mg $\operatorname{prot}^{-1} \mathrm{~h}^{-1}$ ) of pikeperch larvae at 20 DPH fed Artemia enriched with sunflower oil (SFO) or linseed oil (LO) at 3 different salinities (ppt) and incubated with [1-14C]FA substrates. DHA Selco control, 0 ppt (Mean $\pm \mathrm{SD}, \mathrm{n}=3$ ).

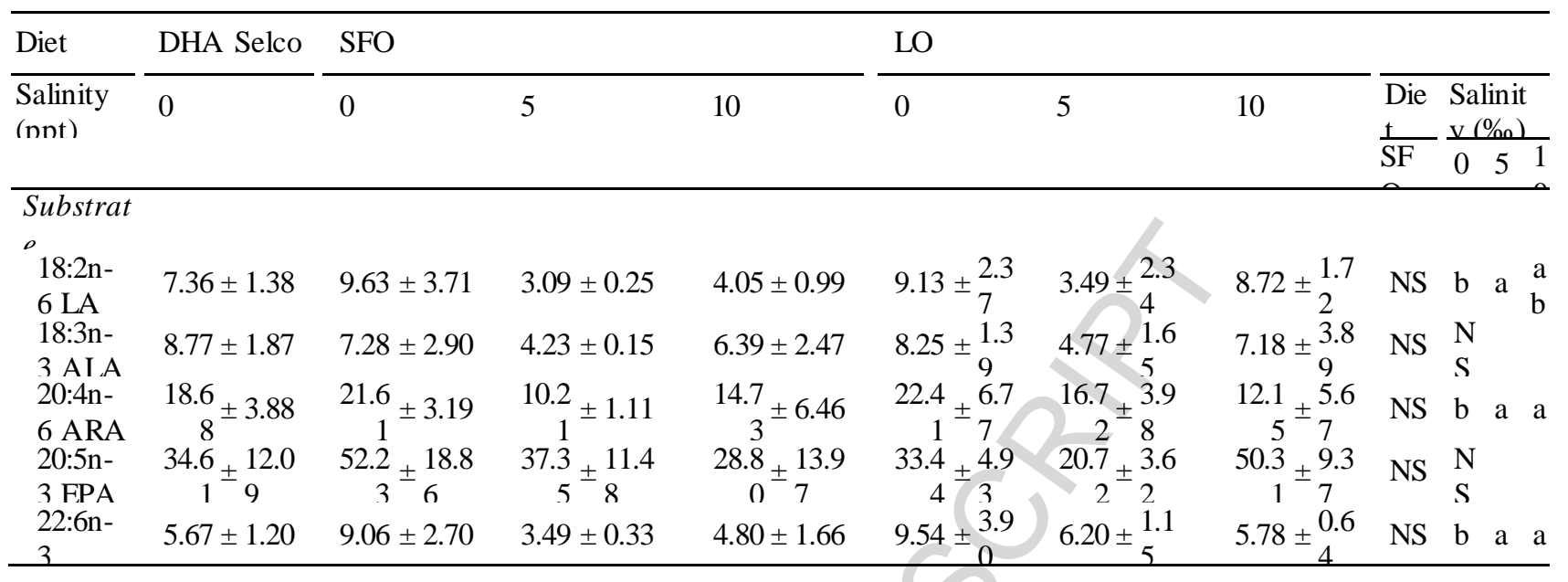

NS, not significant; a, b. For substrates with a significant effect of salinity and no interaction, values without a common letter are significantly different $(\mathrm{P}<0.05)$. 
Table 6. Incorporation of radioactivity into total lipid (pmol mg $\operatorname{prot}^{-1} \mathrm{~h}^{-1}$ ) of pikeperch larvae at 20 $\mathrm{DPH}$ independently of rearing conditions when incubated with [1-14C] FA substrates (Mean $\pm \mathrm{SD}$, $\mathrm{n}=21$ ).

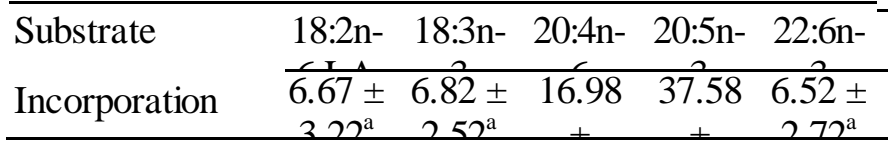

Values followed by a different superscript are significantly different $(\mathrm{P}<0.05)$.

Comparisons between means were performed by one-way ANOVA followed by Tukey's post hoc test . 
Table 7. Eicosanoid content (pg g ww ${ }^{-1}$ ) of pikeperch larvae fed for 30 days with Artemia enriched with sunflower oil (SFO) or linseed oil (LO) at 3 different salinities (ppt), (Mean $\pm \mathrm{SD}, \mathrm{n}=3$ ). DHA Selco control, $0 \mathrm{ppt}$

\begin{tabular}{|c|c|c|c|c|c|c|c|c|c|c|}
\hline Diet & DHA & SFO & & & LO & & & & & \\
\hline \multirow[t]{2}{*}{ Salinity } & \multirow{2}{*}{$\begin{array}{l}0 \\
1 n-3)\end{array}$} & \multirow[t]{2}{*}{0} & \multirow{2}{*}{5} & \multirow[t]{2}{*}{10} & \multirow[t]{2}{*}{0} & \multirow{2}{*}{5} & \multirow[t]{2}{*}{10} & Interaction & Diet & Salinity \\
\hline & & & & & & & & $\begin{array}{l}\text { Diet } v s \\
\text { Salinity }\end{array}$ & $\begin{array}{l}\text { SFO vs } \\
\text { LO }\end{array}$ & $(\% 0)$ \\
\hline $\mathrm{PGE}_{2}$ & \multirow{2}{*}{$\begin{array}{l}5510 \pm \\
\text { 3no } \\
1018 \\
1 \text { 1e }\end{array}$} & \multirow{2}{*}{$\begin{array}{l}5912 \pm \\
1 \text { <07b } \\
1212 \\
\end{array}$} & \multirow{2}{*}{$\begin{array}{l}3313 \pm \\
15^{\mathrm{a}} \\
634 \pm \\
e^{\mathrm{a}}\end{array}$} & \multirow{2}{*}{$\begin{array}{l}3661 \pm \\
111^{a} \\
678 \pm \\
12 n^{a}\end{array}$} & 5754 & \multirow{2}{*}{$\begin{array}{c}4917 \pm \\
111^{\mathrm{a}} \\
997 \pm \\
114^{\mathrm{ab}}\end{array}$} & \multirow{2}{*}{$\begin{array}{l}3810 \pm \\
1217^{\mathrm{a}} \\
618 \pm \\
ح 0^{\mathrm{a}}\end{array}$} & NS & NS & $\mathrm{P} \leq 0.032$ \\
\hline $\mathrm{PGE}_{3}$ & & & & & 1128 & & & NS & NS & $\mathrm{P} \leq 0.028$ \\
\hline
\end{tabular}

Values in a row followed by a different supers cript are significantly different $(\mathrm{P}<0.05)$. 
Table 8. Specific enzymatic activity ( $\mathrm{mU} \mathrm{mg} \operatorname{protein}^{-1} ; \mathrm{U} \mathrm{mg}$ protein $^{-1}$ ) in pikeperch larvae fed for 30 days with Artemia enriched with sunflower oil (SFO) or linseed oil (LO) at 3 different salinities $($ Mean $\pm S D, n=3)$.

\begin{tabular}{|c|c|c|c|c|c|c|c|}
\hline \multirow{2}{*}{$\begin{array}{l}\text { Diet } \\
\text { Salinity }\end{array}$} & \multicolumn{3}{|l|}{ SFO } & \multicolumn{3}{|l|}{ LO } & \\
\hline & 0 & 5 & 10 & 0 & 5 & 10 & Interac \\
\hline Pepsin ${ }^{1}$ & $6.4 \pm 2.4$ & $\mathrm{Nd}$ & $\mathrm{Nd}$ & $6.6 \pm 0.5$ & $\mathrm{Nd}$ & $4.3 \pm 1.1$ & \\
\hline Trypsin ${ }^{1}$ & $15.3 \pm 3.3$ & $12.4 \pm 3.3$ & $14.9 \pm 4.7$ & $11.2 \pm 3.2$ & $12.5 \pm 1.3$ & $7.9 \pm 1.9$ & I \\
\hline Aminopeptidase $\mathrm{N}^{1}$ & $9.3 \pm 0.6$ & $10.7 \pm 1.6$ & $14.6 \pm 2.4$ & 1.2 & $10.2 \pm 2.1$ & $10.4 \pm 1.5$ & N \\
\hline Alkaline phosphatase $\mathrm{AP}^{1}$ & $34.2 \pm 2.3^{\mathrm{a}}$ & $36.3 \pm 2.8^{\mathrm{a}}$ & $45.7 \pm 3.6^{\mathrm{b}}$ & $\pm 4.8^{\mathrm{ab}}$ & $37.7 \pm 5.3^{\mathrm{a}}$ & $38.4 \pm 5.7^{\mathrm{ab}}$ & 0.04 \\
\hline Lipase $^{1}$ & $10.2 \pm 2.1$ & $8.2 \pm 2.1$ & $9.2 \pm 1.6$ & $7.7 \pm 1.5$ & $8.1 \pm 0.6$ & $8.5 \pm 1.5$ & r \\
\hline Leu-ala $^{2}$ & $722.0 \pm 226.0$ & $765.3 \pm 256.5$ & $647.0 \pm 62.4$ & $879.5 \pm 343.6$ & $670.0 \pm 263.4$ & $583.5 \pm 156.6$ & $\mathrm{~N}$ \\
\hline Amylase $^{1}$ & $56.2 \pm 12.4$ & $83.3 \pm 22.6$ & $125.3 \pm 55.9$ & $61.4 \pm 6.2$ & $40.0 \pm 2.9$ & $127.0 \pm 52.5$ & \\
\hline
\end{tabular}

${ }^{1} \mathrm{mU} \mathrm{mg}$ protein ${ }^{-1} ;{ }^{2} \mathrm{U} \mathrm{mg}$ protein ${ }^{-1}$. Values in a row followed by a different superscript are significantly different $\mathrm{P}<0.05$ between experimental diets.

Nd: not detected. DHA Selco control not analysed. * No ANOVA performed on pepsin as value below detection in some treatments. 
Table 9. Incidence of different bone anomalies found in pikeperch larvae fed for 30 days with Artemia enriched with sunflower oil (SFO) or linseed oil (LO) at 3 different salinities (Mean \pm SD, $\mathrm{n}=3$ ). DHA Selco control, $0 \mathrm{ppt}, \mathrm{n}=1$.

\begin{tabular}{|c|c|c|c|c|c|c|c|}
\hline Diet & Control & \multicolumn{3}{|c|}{ SFO } & \multicolumn{3}{|c|}{ LO } \\
\hline Salinity (\%o) & 0 & 0 & 5 & 10 & 0 & 5 & 10 \\
\hline
\end{tabular}

Anomaly Type (\%)

\begin{tabular}{lccccccc} 
Severe & 90 & $76.7 \pm 12.6^{\mathrm{a}}$ & $98.3 \pm 2.9^{\mathrm{b}}$ & $96.7 \pm 5.8^{\mathrm{b}}$ & $81.5 \pm 10.7^{\mathrm{ab}}$ & $86.7 \pm 5.8^{\mathrm{b}}$ & $85.0 \pm 15.0^{\mathrm{ab}}$ \\
$\begin{array}{l}\text { Maxilary } \\
\text { Other cephalic }\end{array}$ & 35 & $58.3 \pm 16.1^{\mathrm{ab}}$ & $83.3 \pm 7.6^{\mathrm{b}}$ & $77.1 \pm 4.9^{\mathrm{b}}$ & $43.7 \pm 17.0^{\mathrm{a}}$ & $81.7 \pm 7.6^{\mathrm{b}}$ & $58.3 \pm 25.2^{\mathrm{ab}}$ \\
$\begin{array}{l}\text { anomalies } \\
\text { Caudal v. scoliosis }\end{array}$ & 55 & $28.3 \pm 22.5$ & $53.3 \pm 7.6$ & $35.8 \pm 19.0$ & $51.7 \pm 6.8$ & $51.7 \pm 10.4$ & $28.3 \pm 5.8$ \\
\hline
\end{tabular}

Values in a row followed by a different superscript are significantly different $(\mathrm{P}<0.05)$ by means of a one-way ANOVA followed by Tukey's post hoc test 
Table 10. Gene expression in pikeperch larvae reared for 30 days with Artemia enriched with sunflower oil (SFO) or linseed oil (LO) at 3 different salinities (Mean $\pm \mathrm{SD}, \mathrm{n}=3$ ). DHA Selco control, 0 ppt.

\begin{tabular}{|c|c|c|c|c|c|c|c|c|}
\hline \multirow{2}{*}{$\begin{array}{l}\text { Diet } \\
\text { Salinity }\end{array}$} & \multirow{2}{*}{$\frac{\text { Control }}{0}$} & \multicolumn{3}{|l|}{ SFO } & \multicolumn{3}{|l|}{ LO } & \multirow[b]{2}{*}{ Interaction } \\
\hline & & 0 & 5 & 10 & 0 & 5 & 10 & \\
\hline Alp & $1 \pm 0$ & $0.196 \pm 0.078$ & $0.228 \pm 0.035$ & $0.363 \pm 0.279$ & $0.268 \pm 0.040$ & $0.246 \pm 0.047$ & $0.141 \pm 0.080$ & NS \\
\hline Twist2 & $1 \pm 0$ & $0.239 \pm 0.112$ & $0.259 \pm 0.147$ & $0.553 \pm 0.332$ & $0.254 \pm 0.108$ & $0.521 \pm 0.169$ & $0.156 \pm 0.077$ & 0.023 \\
\hline $\operatorname{Mef} 2 c$ & $1 \pm 0$ & $0.340 \pm 0.325$ & $0.347 \pm 0.315$ & $0.330 \pm 0.200$ & $0.304 \pm 0.075$ & $0.226 \pm 0.093$ & $0.213 \pm 0.058$ & NS \\
\hline Sox 9 & $1 \pm 0$ & $0.274 \pm 0.210$ & $0.219 \pm 0.102$ & $0.468 \pm 0.471$ & $0.293 \pm 0.078$ & $0.340 \pm 0.150$ & $0.192 \pm 0.059$ & NS \\
\hline
\end{tabular}




\section{References}

Arnold, M.A., Kim, Y., Czubryt, M.P, Phan, D., McAnally, J., Qi, X., Shelton, J.M., Richardson, J.A., Bassel-Duby, R., Olson, E.N., 2007. MEF2C transcription factor controls chondrocyte hypertrophy and bone development. Dev. Cell. 12, 377-389.

Balasubramanian, M.N., Panserat,S., Dupont-Nivet, M., Quillet, E., Montfort, J., Le Cam, A., M Médale, F., Kaushik, S.J., Geurden , I., 2016. Molecular pathways associated with the nutritional programming of plant-based diet acceptance in rainbow trout following an early feeding exposure. BMC Genomics. 17:449 3-20. doi: 10.1186/s12864-016-2804-1.

Bein, R., and Ribi, G., 1994. Effects of larval density and salinity on the development of perch larvae (Perca fluviatilis L.). Aquat. Sci. 56/2, 97-105.

Benedito-Palos, L., Ballester-Lozano, G.F., Simó, P; Karalazos, V., Ortiz, A., Calduch-Giner, J., Pérez-Sánchez, J., 2016. Lasting effects of butyrate and low FM/FO diets on growth performance, blood haematology/biochemistry and molecular growth-related markers in gilthead sea bream (Sparus aurata). Aquaculture 454, 8-18.

Bessey O.A., Lowry O.H., Brock M.J., 1946. Rapid coloric method for determination of alkaline phosphatase in five cubic millimeters of serum. J. Biol. Chem.164: 321-329.

Bialek, P., Kern, B., Yang, X., Schrock, M., Sosic, D., Hong, N., Wu, H., Yu, K., Ornitz, D. M., Olson, E. N., Justice, M.J., Karsenty, G., 2004. A twist code determines the onset of osteoblast differentiation. Dev. Cell 6, 423-435.

Blanchard, G., Makombu, J.G., Kestemont, P., 2008. Influence of different dietary 18:3n-3/18:2n-6 ratio on growth performance, fatty acid composition and hepatic ultrastructure in Eurasian perch, Perca fluviatilis. Aquaculture 284, 144-150.

Boeuf, G., Payan, P., 2001. How should salinity influence fish growth? Comp. Biochem. Physiol. C Toxicol. Pharmacol. 13, 411-423.

Boglino, A., Darias, M.J., Andree, K.B., Estévez, A., Gisbert, E., 2014. The effects of dietary arachidonic acid on bone in flatfish larvae; the last but not the least of the essential fatty acids. J. Appl. Ichthyol. 30, 643-651. 
Boglione, C., Gagliardi, F., Scardi, M., 2001. Skeletal descriptors and quality assessment in larvae and post-larvae of wild-caught and hatchery-reared gilthead sea bream (Sparus aurata L. 1758). Aquaculture 192, 1-22.

Bradford, M., 1976. A rapid and sensitive method for the quantitation of microgram quantities of protein utilizing the principle of protein-dye binding. Anal. Biochem. 72, 248-254.

Bransden, M.P., Butterfield, G.M., Walden, J., McEvoy, L.A., Bell, J.G., 2005. Tank colour and dietary arachidonic acid affects pigmentation, eicosanoid production and tissue fatty acid profile of larval Atlantic cod (Gadus morhua). Aquaculture 250, 328-340.

Brinkmeyer, R.L., Holt, G.J., 1998. Highly unsaturated fatty acids in diets for red drum (Sciaenops ocellatus) larvae. Aquaculture 161, 253-268.

Brown, J.A., Moore, W.M., Quabius, E.S., 2001. Physiological effects of saline waters on zander. Fish Biol. 59, 1544-1555.

Cahu, C.L., Gisbert, E.,Villeneuve, L.A.N., Morais, S., Hamza, N., Wold, P-A., Zambino Infante, J.L., 2009. Influence of dietary phospholipids on early ontogenesis of fish. Aquac. Res. 40, 989999.

Chen, J., Xia, J., Yu, Y.L., Wang, S.Q., Wei, Y.B., Chen, F.Y., Huang, G.Y., Shi, J.S., 2014. HDAC5 promotes osteosarcoma progression by upregulation of Twist 1 expression. Tum. Biol. 35, $1383-1387$.

Choe, K.P., Havird, J., Rose, R., Hyndman, K., Piermarini, P., Evans, D.H., 2006. COX2 in a euryhaline teleost, Fundulus heteroclitus: primary sequence, distribution, localization, and potential function in gills during salinity acclimation. J. Exp. Biol. 209, 1696-1708.

Claiborne, J.B., Walton, J.S., Compton-McCullough, D., 1994. Acid-base regulation, branchial transfers and renal output in a marine teleost fish (the long-horned sculpin Myoxocephalus octodecimspinosus) during exposure to low salinities. J. Exp. Biol.193, 79-85.

Conceição, L., Morais, S., Rønnestad, I. 2007. Tracers in fish larvae nutrition: A review of methods and applications. Aquaculture 267, 62-75.

Craig, J.F., 2000. Percid Fishes. Systematics, Ecology and Exploitation. Blackwell Science, London. $352 \mathrm{pp}$. 
Cuvier-Péres A., Kestemont P., 2002. Development of some digestive enzymes in Eurasian perch larvae Perca fluviatilis. Fish Physiol. Biochem. 24, 279-285.

Dalsgaard, J., Lund, I., Thorarinsdottir, R., Drengstig, A., Arvonen, K., Pedersen, P.B., 2013. Farming different species in RAS in Nordic countries: Current status and future perspectives. Aquac. Engin. 53, 2-13.

Dantagnan, P., Borquez, A., Hernandez, A., Izquierdo, M., 2010. Effect of EPA/DHA ratios on the growth and survival of Galaxias maculatus (Jenyns, 1842) larvae reared under different salinity regimes. Aquac. Res. 41: 239-244.

Dantagnan, P., Bórquez, A., Pavez, C., Hernández, A., 2013. Feeding $\omega-3$ PUFA enriched rotifers to Galaxias maculatus (Jenyns, 1842) larvae reared at different salinity conditions: effects on growth parameters, survival and fatty acids profile. Lat. Am. J. Aquat. Res. 41, 404-411.

Deane, E.E., Woo Norman, Y.S., 2009. Modulation of fish growth hormone levels by salinity, temperature, pollutants and aquaculture related stress: A review. Rev. Fish Biol. Fish. 19, 97-120.

Emery, J.A., Herman, K., Hamid, N.K.A.,Donald, J., Turchini, G.M. (2013). $\Delta$ - desaturase substrate competition: Dietary linoleic acid (18:2n-6) has only trivial effects on a-linolenic acid (18:3n-3) bioconversion in the teleost rainbow trout. Plos One, 8, e57463, 1-9.

Folch, J., Lees, M., Stanley, G.H.S., 1957. A simple method for the isolation and purification of total lipids from animal tissues. J. Biol. Chem. 226, 497-509.

Fonseca- Madrigal, J., Pineda- Delagado, D., Martinez-Palacios, C., Rodriguez, C., Tocher, D.R., 2012. Effect of salinity on the biosynthesis of n-3 long-chain polyunsaturated fatty acids in silverside Chirostoma estor. Fish Physiol. Biochem. 38, 1047-1057.

Geurden, I., Borchert, P., Balsubramanian, M., Schrama, J., Dupont-Nivet, M., Quillet, E., Kaushik, S., Panserat, P., Médale, F., 2013. Early-feeding exposure to a plant- based diet improves its future acceptance and utilization in rainbow trout. Commun. Agric. Appl. Biol. Sci. 78, 157-160.

Gheisvandi, N., Hajimoradloo, A., Hoseinifar, S.H., 2015. The effects of gradual or abrupt changes in salinity on digestive enzymes activity of Caspian kutum, rutilus kutum (Kamensky, 1901) larvae. J. App. Icht. 31, 1107-1112. 
Gisbert E., Villeneuve L., Zambonino-Infante J.L., Quazuguel P., Cahu C.L., 2005. Dietary phospholipids are more efficient than neutral lipids for long-chain polyunsaturated fatty acid supply in European sea bass Dicentrarchus labrax larval development. Lipids 40, 609-618.

Gisbert, E., Giménez, G., Fernández, I., Kotzamanis, Y., Estévez, A., 2009. Development of digestive enzymes in common dentex Dentex dentex during early ontogeny. Aquaculture 287, 381387.

Hamza, N., Mhetli, M., Ben-Khemis, I., Cahu, C., Kestemont, P., 2008. Effect of dietary phospholipid levels on performance, enzyme activities and fatty acid composition of pikeperch (Sander lucioperca) larvae. Aquaculture 275, 274-282.

Hamza, N., Kestemont, P., Ben Khemis, I., Mhetli, M., Cahu, C., 2012. Effect of different sources and levels of dietary phospholipids on performances and fatty acid composition of pikeperch (Sander lucioperca) larvae. Aquac. Nutr. 18, 249-257.

Helland, S., Terjesen, B.F., Berg, L., 2003. Free amino acid and protein content in the planktonic copepod Temora longicornis compared to Artemia franciscana. Aquaculture 215, 213-228.

Hessle, L., Narisawa, S., Iwasaki, A., Johnson, K., Terkeltaub, R., Millan, J.L., 2002. Mechanisms that regulate normal bone mineral deposition: A hypothesis on the role of antagonistic pathways in preventing hypo- and hyper-mineralization. Biomedical and Health Research 54, 117-125.

Holm H., Hanssen L.E., Krogdahl A., Florholmen J., 1988. High and low inhibitor soybean meals affect human duodenal proteinase activity differently: in vivo comparison with bovine serum albumin. J. Nutr. 118: 515-520.

Iijima, N., Tanaka, S., Ota, Y., 1998. Purification and characterization of bile salt-activated lipase from the hepatopancreas of red sea bream, Pagrus major. Fish Physiol. Biochem. 18, 59-69.

Izquierdo, M.S., Watanabe, T., Takeuchi, T., Arakawa, T., Kitajima, C., 1989. Requirement of larval red sea bream, Pagrus major, for essential fatty acids. Nipp. Suis. Gakkaishi 55, 859-867.

Izquierdo, M.S., Scolamacchia, M., Betancor, M., Roo, J., Caballero, M.J., Terova, G., Witten, P. E., 2013. Effects of dietary DHA and alpha-tocopherol on bone development, early mineralisation and oxidative stress in Sparus aurata (Linnaeus, 1758) larvae. Br. J. Nutr. 109, 1796-1805.

Izquierdo, M.S., Koven, W., 2010. Lipids. On Larval Fish Nutrition, J. Holt Ed. Wiley-Blackwell, John Wiley and Sons Publishers, pp: 47-82. 
Kestemont, P., Dabrowski, K., Summerfelt, R.C., (Eds) 2015. Biology and Culture of Percid Fishes - Principles and Practices. Springer, The Netherlands, 901 pp.

Koven, W.M., Barr, Y., Lutzky, S., Ben-Atia, I., Weiss, R., Harel, M., Behrens, P., Tandler, A., 2001. The effect of dietary arachidonic acid (20:4n-6) on growth, survival and resistance to handling stress in gilthead seabream (Sparus aurata) larvae. Aquaculture 193, 107-122.

Koven, W.M., Van Anholt, R.D., Lutsky, S., Ben Atia, I., Nixon, O., Ron, B., Tandler, A., 2003 The effect of dietary arachidonic acid on growth, survival, and cortisol levels in different-age gilthead seabream larvae (Sparus auratus) exposed to handling or daily salinity change. Aquaculture 228, 307-320.

Kronenberg, H.M., 2004. Twist genes regulate Runx2 and bone formation. Dev. Cell. 6(3), 317318.

Lall, S.P., Lewis-McCrea, L.M., 2007. Role of nutrients in skeletal metabolism and pathology in fish-an overview. Aquaculture 267, 3-19.

Li, Y.Y., Zheng, Y.J. Hu, C.B., Xia, X., Xu, W.J., Chen, W.Z., Sun, Z.W., Huang, J.H., 2008. Comparison of capability in utilizing linoleic and alpha-linolenic acids in euryhaline rabbitfish Siganus oramin reared in different ambient salinity. Comp. Biochem. Physiol. Part C 148, 456-457.

Liland, N.S., Hatlen, B., Takle, H., Venegas, C., Espe, M., Torstensen, B.E., Waagbø, R., 2015. Including processed poultry and porcine by-products in diets high in plant ingredients reduced liver TAG in Atlantic salmon, Salmo salar L. Aquac. Nutr. 21, 655-669.

Lowry, O.H., Rosebrough, N.J., Farr, A.L., Randall, R.J., 1951. Protein measurements with the folin phenol reagent. J. Biol. Chem. 193, 265-275.

Lund, I., Høglund, E., Ebbesson, L.O., Skov, P.V., 2014. Dietary LC-PUFA deficiency early in ontogeny induces behavioural changes in pike perch (Sander lucioperca) larvae and fry. Aquaculture 432, 453-461.

Lund, I, El Kertaoui, N., Izquierdo, M.S.; Dominiguez, D., Hansen, B.W., Kestemont, P., 2017. Importance of phospholipid supplementation combined with LC-PUFAs in diets for pikeperch (Sander lucioperca) larvae. Unpublished results (submitted to Br. J. Nutr.)

Lund, I, Steenfeldt, S.J., 2011. The effects of dietary long chain essential fatty acids on growth and stress tolerance in pikeperch larvae (Sander lucioperca L.). Aquac. Nutr. 17, 191-199. 
Maroux, S., Louvard, D., Barath, J., 1973. The aminopeptidase from hog intestinal brush border. Biochim. Biophys. Acta 321, 282-295.

Metais, P., Bieth, J., 1968. Determination of alpha-amylase using a microtechnique. Annal. Biol. Clin. 26, 133-142.

Nicholson, J., Kim, Y., 1975. A one-step L-amino acid oxidase assay for intestinal peptide hydrolase activity. Anal. Biochem. 63, 110-117.

Olsen, Y., Evjemo, J. O., Kjorsvik, E., Larssen, H., Li, K., Overrein, I., Rainuzzo, J., 2014. DHA content in dietary phospholipids affects DHA content in phospholipids of cod larvae and larval performance. Aquaculture 428, 203-214.

Overton, J.L., Bayley, M., Paulsen, H., Wang, T., 2008. Salinity tolerance of cultured Eurasian perch, Perca fluviatilis L.: Effects on growth and on survival as a function of temperature. Aquaculture 277, 282-286.

Overturf, K., Barrows, F.T., Hardy, R.W., Brezas, A., Dumas, A., 2016. Energy composition of diet affects muscle fiber recruitment, body composition, and growth trajectory in rainbow trout (Oncorhynchus mykiss). Aquaculture 457, 1-14

Reis, D.B, Acosta, N.G., Almansa, E., Navarro, J.C., Tocher, D.R., Monroig, O., Andrade, J.P., Sykes, A.V., Rodríguez, C., 2014. In vivo metabolism of unsaturated fatty acids in Octopus vulgaris hatchlings determined by incubation with 14C-labelled fatty acids added directly to seawater as protein complexes. Aquaculture 431, 28-33.

Reis, D.B., Acosta, N.G., Almansa, E., Navarro, J.C., Tocher, D.R., Andrade, J.P., Sykes, A.V., Rodríguez, C. 2017. Comparative study on fatty acid metabolism of early stages of two crustacean species: Artemia sp. metanauplii and Grapsus adscensionis zoeae, as live prey for marine animals. Comp. Biochem. Physiol. Part B 204, 53-60.

Renn, J., Schaedel, M., Volff, J.N., Goerlich, R., Schartl, M., Winkler, C., 2006. Dynamic expression of sparc precedes formation of skeletal elements in the medaka (Oryzias latipes). Gene 372, 208-21.

Renn, J., Winkler, C., 2009. Osterix-mCherry transgenic medaka for in vivo imaging of bone formation. Dev. Dyn. 238, 241-248. 
Rønnestad, I., Thorsen, A., Roderick, N.F., 1999. Fish larval nutrition: a review of recent advances in the roles of amino acids. Aquaculture 177, 201-216.

Saleh, R., Betancor, M.B., Roo, J., Benítez-Santana, T., Hernández-Cruz, C.M., Moyano, F.J., Izquierdo, M., 2013a. Optimum krill phospholipids content in microdiets for gilthead seabream (Sparus aurata) larvae. Aquac. Nutr. 19, 449-460.

Saleh, R., Betancor, M.B., Roo, J., Benítez-Santana, T., Hernández-Cruz, C.M., Moyano, F.J., Izquierdo, M., 2013b. Optimum soybean lecithin contents in microdiets for gilthead seabream (Sparus aurata) larvae. Aquac. Nutr. 19, 585-597.

Takeuchi, T., 1997. Essential fatty acid requirements of aquatic animals with emphasis on fish larvae and fingerlings. Rev. Fish. Sci. 5, 1-25.

Takeuchi, T., Toyota, M., Watanabe, T., 1991. Dietary value to red sea bream of Artemia nauplii enriched with EPA and DHA. Abstracts of the Annual Meeting of Japanese Society of Scientific Fisheries, Tokyo, pp. 243.

Tocher, D.R., 2003. Metabolism and functions of lipids and fatty acids in teleost fish. Rev. Fish. Sci. 11, 107-184.

Tocher, D.R., 2010. Fatty acid requirements in ontogeny of marine and freshwater fish. Aquac. Res. 41, 717-732.

Vagner, M., Santigosa, E., 2011. Characterization and modulation of gene expression and enzymatic activity of delta-6 desaturase in teleosts: A review. Aquaculture 315, 131-141.

Vandewalle, P., Gluckmann, I., Wagemans, F., 1998. A critical assessment of the alcian blue/alizarin double staining in fish larvae and fry. Belg. J. Zool. 128, 93-95.

Watanabe, T., 1993. Importance of docosahexaenoic acid in marine larval fish. J. World Aquac. Soc. $24,152-161$

Witten, P.E., Huysseune, A., 2009. A comparative view on mechanisms and functions of skeletal remodelling in teleost fish, with special emphasis on osteoclasts and their function. Biol. Rev. 84, 315-346.

Worthington, T.M., 1982. Enzymes and related biochemicals. Biochemical Products Division. Worthington Diagnostic System Freehold, NJ 
Xie, D., Wang, S., You, C., Chen, F., Tocher, D.R., Li, Y., 2015. Characteristics of LC-PUFA biosynthesis in marine herbivorous teleost Siganus canaliculatus under different ambient salinities. Aquac. Nutr. 21, 541-551.

$\mathrm{Xu}$, X., Kestemont P., 2002. Lipid metabolism and FA composition in tissues of Eurasian perch Perca fluviatilis tissues as influenced by dietary fats. Lipids 37, 297-304.

Yan, Y.-L., Miller, C.T., Nissen, R., Singer, A., Liu, D., Kirn, A., Draper, B., Willoughby, J., Morcos, P.A., Amsterdam, A., Chung, B.-C., Westerfield, M., Haffter, P., Hopkins, N., Kimmel, C., Postlethwait, J.H., 2002. A zebrafish sox9 gene required for cartilage morphogenesis. Development $129,5065-5079$.

Zheng, X., Torstensen, B.E., Tocher, D.R., Dick, J.R., Henderson, R.J., Bell J.G., 2005. Environmental and dietary influences on highly unsaturated fatty acid biosynthesis and expression of fatty acyl desaturase and elongase genes in liver of Atlantic salmon (Salmo salar) Biochim. Biophys. Acta - Molecular and Cell Biology of Lipids 1734, 13-24. 


\section{Highlights:}

- Results pointed out that pikeperch larvae have a low capability to desaturate and elongate n3 and n-6 PUFAs despite environmental salinities.

- Rearing salinity conditions up to $10 \mathrm{ppt}$ have limited effects on growth or survival of larvae, but affected endocrine hormonal prostaglandin production.

- Larval proteolytic enzymatic capability was significantly affected by dietary origin of LA or ALA.

- The results pointed out a high occurrence of anomalies in endochondral bones and the increased incidence at higher salinities. 


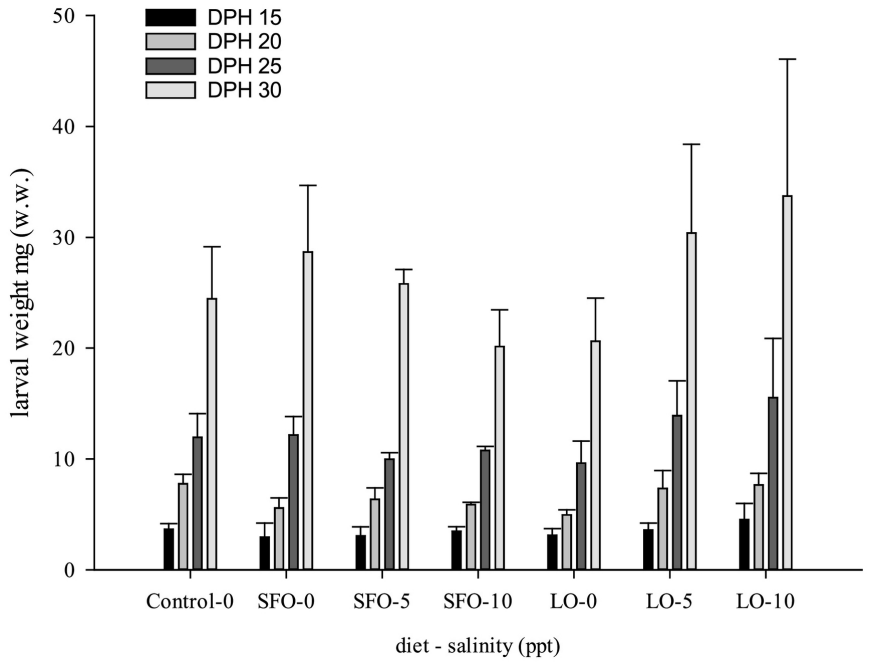

Figure 1 


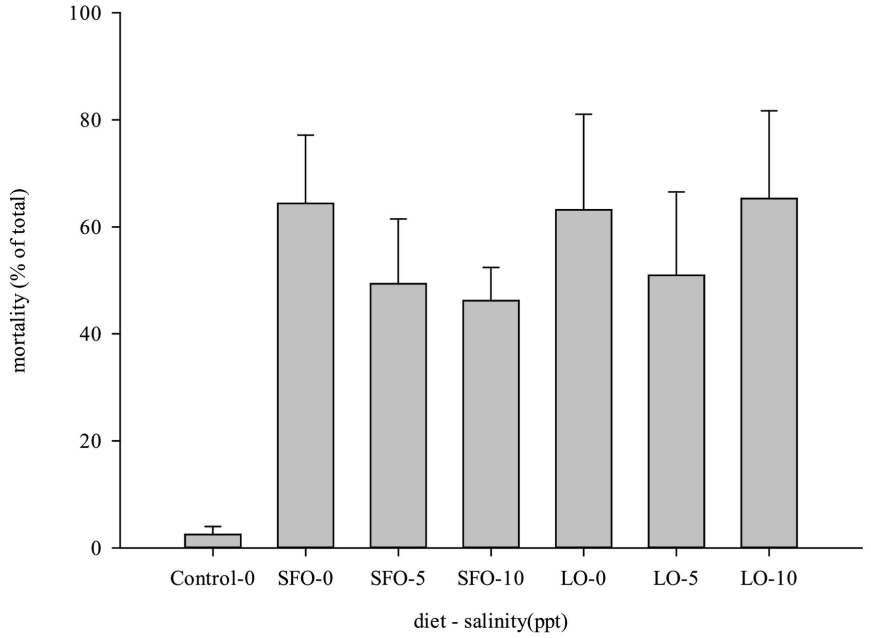

Figure 2 
a

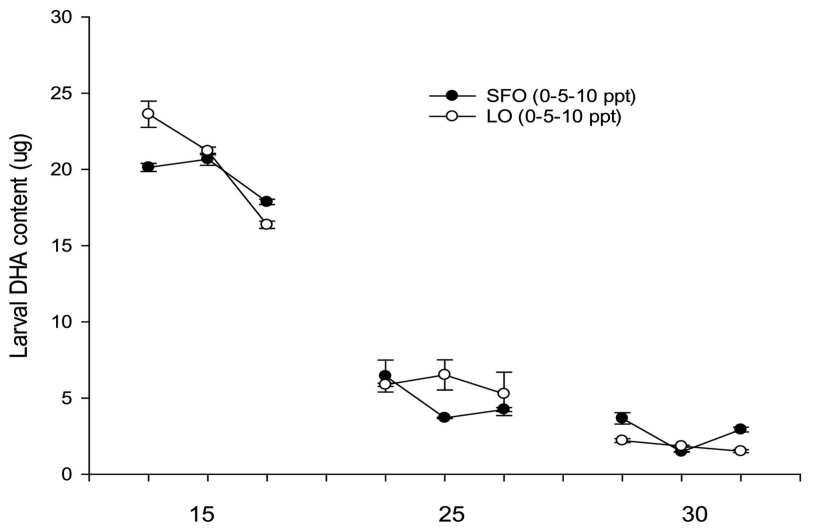

days post hatch

b

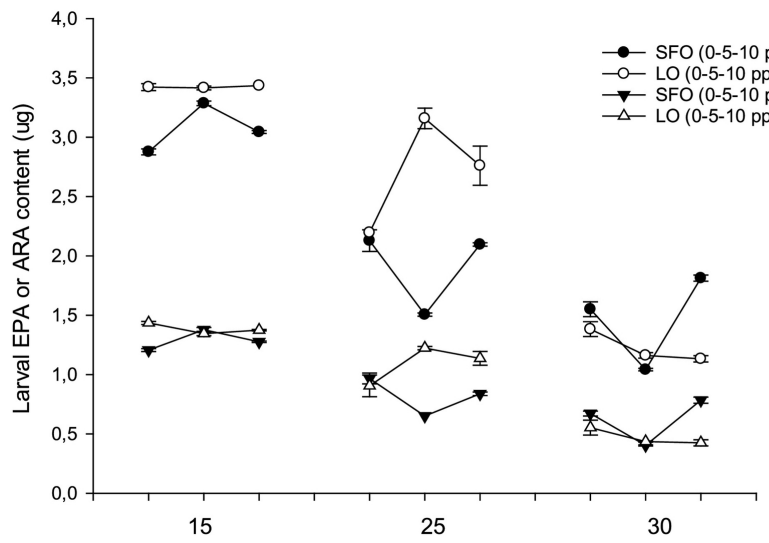

days post hatch

Figure 3 